\title{
Enhancement of the aerosol direct radiative effect by semi-volatile aerosol components: airborne measurements in North-Western Europe
}

\author{
W. T. Morgan ${ }^{1}$, J. D. Allan ${ }^{1,2}$, K. N. Bower ${ }^{1}$, M. Esselborn ${ }^{3, *}$, B. Harris ${ }^{4}$, J. S. Henzing ${ }^{5}$, E. J. Highwood ${ }^{4}$, \\ A. Kiendler-Scharr ${ }^{6}$, G. R. McMeeking ${ }^{1}$, A. A. Mensah $^{6}$, M. J. Northway ${ }^{4}$, S. Osborne ${ }^{7, * *}$, P. I. Williams ${ }^{1,2}$, R. Krejci ${ }^{8}$, \\ and H. Coe ${ }^{1}$ \\ ${ }^{1}$ Centre for Atmospheric Science, University of Manchester, Manchester, UK \\ ${ }^{2}$ National Centre for Atmospheric Science, University of Manchester, Manchester, UK \\ ${ }^{3}$ Institut für Physik der Atmosphäre, Deutsches Zentrum für Luft-und Raumfahrt (DLR), Oberpfaffenhofen, Germany \\ ${ }^{4}$ Department of Meteorology, University of Reading, UK \\ ${ }^{5}$ TNO, Utrecht, The Netherlands \\ ${ }^{6}$ Institute for Chemistry and Dynamics of the Geosphere, Institute 2: Troposphere, Research Centre Jülich, Jülich, Germany \\ ${ }^{7}$ Met Office, Exeter, UK \\ ${ }^{8}$ Department of Applied Environmental Science, Atmospheric Science Unit, Stockholm University, Sweden \\ *now at: European Southern Observatory (ESO), 85748 Garching bei München, Germany \\ *** now at: Met Office, Cardington, UK
}

Received: 6 April 2010 - Published in Atmos. Chem. Phys. Discuss.: 22 April 2010

Revised: 26 August 2010 - Accepted: 28 August 2010 - Published: 1 September 2010

\begin{abstract}
A case study of atmospheric aerosol measurements exploring the impact of the vertical distribution of aerosol chemical composition upon the radiative budget in North-Western Europe is presented. Sub-micron aerosol chemical composition was measured by an Aerodyne Aerosol Mass Spectrometer (AMS) on both an airborne platform and a ground-based site at Cabauw in the Netherlands. The examined period in May 2008 was characterised by enhanced pollution loadings in North-Western Europe and was dominated by ammonium nitrate and Organic Matter (OM). Both ammonium nitrate and OM were observed to increase with altitude in the atmospheric boundary layer. This is primarily attributed to partitioning of semi-volatile gas phase species to the particle phase at reduced temperature and enhanced relative humidity. Increased ammonium nitrate concentrations in particular were found to strongly increase the ambient scattering potential of the aerosol burden, which was a consequence of the large amount of associated water as well as the enhanced mass. During particularly polluted con-
\end{abstract}

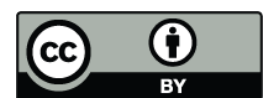

Correspondence to: $\mathrm{W}$. T. Morgan (will.morgan@manchester.ac.uk) ditions, increases in aerosol optical depth of $50-100 \%$ were estimated to occur due to the observed increase in secondary aerosol mass and associated water uptake. Furthermore, the single scattering albedo was also shown to increase with height in the boundary layer. These enhancements combined to increase the negative direct aerosol radiative forcing by close to a factor of two at the median percentile level. Such increases have major ramifications for regional climate predictions as semi-volatile components are often not included in aerosol models.

The results presented here provide an ideal opportunity to test regional and global representations of both the aerosol vertical distribution and subsequent impacts in North-Western Europe. North-Western Europe can be viewed as an analogue for the possible future air quality over other polluted regions of the Northern Hemisphere, where substantial reductions in sulphur dioxide emissions have yet to occur. Anticipated reductions in sulphur dioxide in polluted regions will result in an increase in the availability of ammonia to form ammonium nitrate as opposed to ammonium sulphate. This will be most important where intensive agricultural practises occur. Our observations over NorthWestern Europe, a region where sulphur dioxide emissions

Published by Copernicus Publications on behalf of the European Geosciences Union. 
have already been reduced, indicate that failure to include the semi-volatile behaviour of ammonium nitrate will result in significant errors in predicted aerosol direct radiative forcing. Such errors will be particularly significant on regional scales.

\section{Introduction}

The radiative impact of anthropogenic aerosols is often most keenly felt upon regional scales due to its shorter life-time compared to greenhouse gases (e.g. Charlson et al., 1992). This is particularly evident over industrialized regions of the Northern Hemisphere such as North America, Europe and Asian countries such as India and China. Characterisation of aerosol chemical components and associated processes is paramount in order to assess the direct and indirect radiative forcing of atmospheric aerosol (e.g. Forster et al., 2007). Such assessments are traditionally undertaken via employment of global or regional scale models. However, these often produce wildly differing results due to the complexity of representing atmospheric aerosol (Kinne et al., 2006; Textor et al., 2006). One such complexity is the representation of semi-volatile compounds.

Traditionally, thermodynamical treatments of nitrate have not been included in global circulation models due to such difficulties (e.g. Myhre et al., 2006), although it has received more attention in global and regional chemical transport models (e.g. Schaap et al., 2004; Myhre et al., 2006). These intricacies also apply to representation of semi-volatile organic compounds. Ammonium nitrate and Organic Matter $(\mathrm{OM})$ are two of the most abundant aerosol components in polluted regions of Europe (e.g. Putaud et al., 2004). Furthermore, the relative importance of such species to the aerosol burden in Europe is liable to further increase in the future due to the substantial reductions in sulphur dioxide that have occurred over the last 30 years (Monks et al., 2009). A key observation of previous studies in Western Europe is that nitrate is the dominant component during periods of high pollutant concentrations (Putaud et al., 2004; Morgan et al., 2009, 2010). Furthermore, ammonium nitrate has been shown to be a major contributor to aerosol light scattering in Western Europe based upon ground-based measurements (e.g. Diederen et al., 1985; Brink et al., 1996).

The vertical distribution of aerosol chemical components is a key parameter governing the radiative balance of the climate system (Textor et al., 2006). Deficiencies in its representation in global aerosol models produce significant uncertainties in estimates of the aerosol direct effect (Textor et al., 2006). Vertical profiles of ammonium nitrate, a semi-volatile inorganic salt, indicate that concentrations regularly peak at the top of the boundary layer (Neuman et al., 2003; Morino et al., 2006; Crosier et al., 2007; Morgan et al., 2009). Such observations have been attributed to the equilibrium between gas phase nitric acid $\left(\mathrm{HNO}_{3}\right)$, ammonia $\left(\mathrm{NH}_{3}\right)$ and particulate ammonium nitrate $\left(\mathrm{NH}_{4} \mathrm{NO}_{3}\right)$, which favours the particle phase at reduced temperature and enhanced relative humidity typical of the top of the boundary layer.

A growing body of evidence (Donahue et al., 2006; Robinson et al., 2007; Huffman et al., 2009; Jimenez et al., 2009) has recently highlighted the semi-volatile nature of the OM component of the atmospheric aerosol burden. Thus enhancement of the OM component could occur at the top of the boundary layer due to condensation to the particle phase in a similar manner to ammonium nitrate. Such a process could have major implications, as OM has been shown to dominate the sub-micron aerosol burden in many polluted locations across the Northern Hemisphere (Zhang et al., 2007). Furthermore, Zhang et al. (2007) indicated that the Secondary Organic Aerosol (SOA) component dominated on regional scales when compared to Primary Organic Aerosol (POA). Recent studies have shown that the more volatile fraction of the SOA dominates during the initial stages of oxidation, whereas lower volatility SOA is observed to be the largest fraction once the OM has aged appreciably (Morgan et al., 2010; Ng et al., 2010). Thus on continental scales such as North-Western Europe, the semi-volatile behaviour of OM may be highly important. Furthermore, the major contribution of $\mathrm{OM}$ and ammonium nitrate is not a situation specific to North-Western Europe. For example, the state of California in the USA is a region where both ammonium nitrate (e.g. White and Roberts, 1977; Neuman et al., 2003) and SOA (e.g. Docherty et al., 2008) are prevalent. Thus there is significant potential for perturbation of the radiative balance of the climate system on regional scales via addition of particulate mass by condensation of semi-volatile aerosol precursors.

Morgan et al. (2010) presented an overview of the aerosol chemical composition measurements from the UK Facility for Airborne Atmospheric Measurements (FAAM) BAe-146 research aircraft during the European Integrated Project on Aerosol Cloud Climate and Air Quality Interactions (EUCAARI, Kulmala et al., 2009) airborne intensive observation period. The study highlighted the ubiquity of OM across Europe and the dominance of ammonium nitrate during major pollution events in North-Western Europe. Two major OM components were identified; Low-Volatility Oxygenated Organic Aerosol (LV-OOA) and Semi-Volatile Oxygenated Organic Aerosol (SV-OOA), which correspond to more processed OM and fresher OM respectively (Jimenez et al., 2009). The spatial distribution of aerosol chemical composition indicated that the maximum pollution loading during a period dominated by anticyclonic conditions was located in North-Western Europe, specifically in the Netherlands region and the immediate outflow from it into the North Sea and English Channel. Such conditions were dominated by ammonium nitrate and the fractional contribution of the SVOOA component to the OM was enhanced. This was a reflection of the proximity to major sources in North-Western 
Europe, where the nitrogen oxide and ammonia source fields reach their maximum (Reis et al., 2009).

The focus of this manuscript is upon the identified enhanced pollution in North-Western Europe and its relationship with aerosol optical properties and the aerosol direct effect on climate. This is achieved via comparison of the coincident chemical composition measurements from the BAe-146 aircraft and a ground-based site at Cabauw, in the Netherlands. These measurements are complemented by remote sensing measurements from several ground-based locations in Western Europe. Particular focus is given to the vertical distribution of the chemical components and how this relates to the radiative impact of the aerosol burden.

\section{Method}

The EUCAARI airborne observation period included parallel studies known as the EUCAARI-LONG Range EXperiment (EUCAARI-LONGREX, henceforth referred to as LONGREX) and the Intensive Observation Period at Cabauw Tower (IMPACT). This analysis will focus upon flight missions conducted by the BAe-146 research aircraft when it operated in the vicinity of a ground-based measurement tower at Cabauw, in the Western Netherlands. Cabauw served as the ground-based component and base of IMPACT, while the BAe-146 operated as a part of LONGREX. Flights in this area were characterised by high pollution loadings and predominantly cloud-free conditions. The selected flights are summarised in Table 1 and Fig. 1.

A suite of instrumentation capable of determining the chemical composition, microphysical, optical and hygroscopic properties of the atmospheric aerosol burden was utilised on the FAAM BAe-146 research aircraft during the LONGREX flying period. The BAe-146 flew in conjunction with the Deutsches Zentrum für Luft-und Raumfahrt (DLR) Falcon 20-E5 (e.g. Wandinger et al., 2002), which operated a LIDAR system that included a High Spectral Resolution LIDAR mode (HSRL, Esselborn et al., 2008). The HSRL measured aerosol backscatter and extinction coefficients in real time, which allowed identification of pollution plumes and subsequent sampling in-situ by the BAe146. The Cabauw ground-based site is located in the Western Netherlands $\left(51^{\circ} 58.223^{\prime} \mathrm{N}, 4^{\circ} 55.575^{\prime} \mathrm{E}\right.$, shown in Fig. 1) in a predominantly agricultural setting, thus the site is largely representative of the wider region (Van Ulden and Wieringa, 1996). The aerosol instrumentation at the site sampled from a $60 \mathrm{~m}$ high inlet. Additionally, regular radiosonde launches from Cabauw were conducted during the study. An AErosol RObotic NETwork (AERONET, Holben et al., 1998) station is also located at Cabauw. Details of the relevant instrumentation utilised from the ground-based site at Cabauw and the BAe-146 are summarised in Table 2.

\subsection{Aerosol chemical composition}

A Droplet Measurement Technologies (DMT) Single Particle Soot Photometer (SP2, Stephens et al., 2003; Baumgardner et al., 2004) measured Black Carbon (BC) mass and the number of particles containing a $\mathrm{BC}$ core as a function of particle size over a diameter range of $55-400 \mathrm{~nm}$ assuming an ambient $\mathrm{BC}$ density of $1.8 \mathrm{~g} \mathrm{~cm}^{-3}$. The detection efficiency for $\mathrm{BC}$ particles at the smallest sizes may be less than $100 \%$ (Schwarz et al., 2010). In order to improve determination of the optical size of absorbing particles, the SP2 was modified to include a four-element avalanche photodiode (Gao et al., 2007).

Size-resolved chemical composition information of nonrefractory particulate matter of widely varying volatility was measured by an Aerodyne compact Time-of-Flight Aerosol Mass Spectrometer (cToF-AMS, Drewnick et al., 2005; Canagaratna et al., 2007) onboard the BAe-146. Previous studies (Crosier et al., 2007; Morgan et al., 2009) have included detailed information regarding the sampling strategy of the AMS on the BAe-146. Morgan et al. (2010) included specific information regarding the quantification and analysis of the BAe-146 AMS data pertinent to this study. Details regarding the derivation of size-resolved chemical composition from the AMS on the BAe-146 is included in Appendix A. Additionally, a High-Resolution Time-of-Flight AMS (HRToF-AMS, DeCarlo et al., 2006; Canagaratna et al., 2007) was deployed at Cabauw during the study (Mensah, 2010), providing complementary chemical composition data to the airborne cToF-AMS. The AMS uses an aerodynamic lens system (Liu et al., 1995a,b) which has $100 \%$ transmission for 40-700 nm vacuum aerodynamic diameter (DeCarlo et al., 2004) particles. Mass concentration values are reported as micrograms per standard cubic metre $\left(\mu \mathrm{g} \mathrm{sm}^{-3}\right)$ i.e. at Standard Temperature and Pressure (STP) of $273.15 \mathrm{~K}$ and $1013.25 \mathrm{hPa}$ respectively. The aerosol physical and optical properties detailed in the following section are also converted to STP in order to compare with the AMS measurements.

\subsection{Aerosol physical and optical properties}

A wing-mounted Particle Measurement Systems (PMS) Passive Cavity Aerosol Spectrometer Probe 100X (PCASP, Liu et al., 1992; Strapp et al., 1992) was used to measure dry number-size distributions of the aerosol burden. This is achieved via optical counting and sizing of particles across 15 channels over a diameter size range of $0.1-3 \mu \mathrm{m}$. Particle size is determined via experimental calibrations using Di-Ethyl-Hexyl-Sebacate (DEHS), which is converted to a Polystyrene Latex Sphere (PSL) equivalent size.

The optical characteristics of the aerosol burden were determined using a TSI 3563 Nephelometer (Anderson et al., 1996) and a Radiance Research Particle Soot Absorption Photometer (PSAP, Bond et al., 1999). The operational procedures for these systems on the BAe-146 have been 
Table 1. Flight summary of the operations included in this study. All flights were conducted during 2008. Also included are the times when the BAe-146 operated in the vicinity of Cabauw.

\begin{tabular}{|c|c|c|c|c|}
\hline Flight & Date & Start & End & Sortie Objectives \\
\hline B362 & 6 May & $11: 03$ & $11: 23$ & $\begin{array}{l}\text { Map pollution outflow from Central Europe towards UK and } \\
\text { North Sea. }\end{array}$ \\
\hline B366 & 8 May & $15: 04$ & 16:04 & $\begin{array}{l}\text { Survey Northern Germany and Netherlands to probe pollution } \\
\text { gradient extending from east to west. }\end{array}$ \\
\hline B379 & 21 May & $11: 16$ & $12: 22$ & $\begin{array}{l}\text { Survey Northern Germany and Netherlands to probe pollution } \\
\text { gradient extending from east to west. }\end{array}$ \\
\hline
\end{tabular}
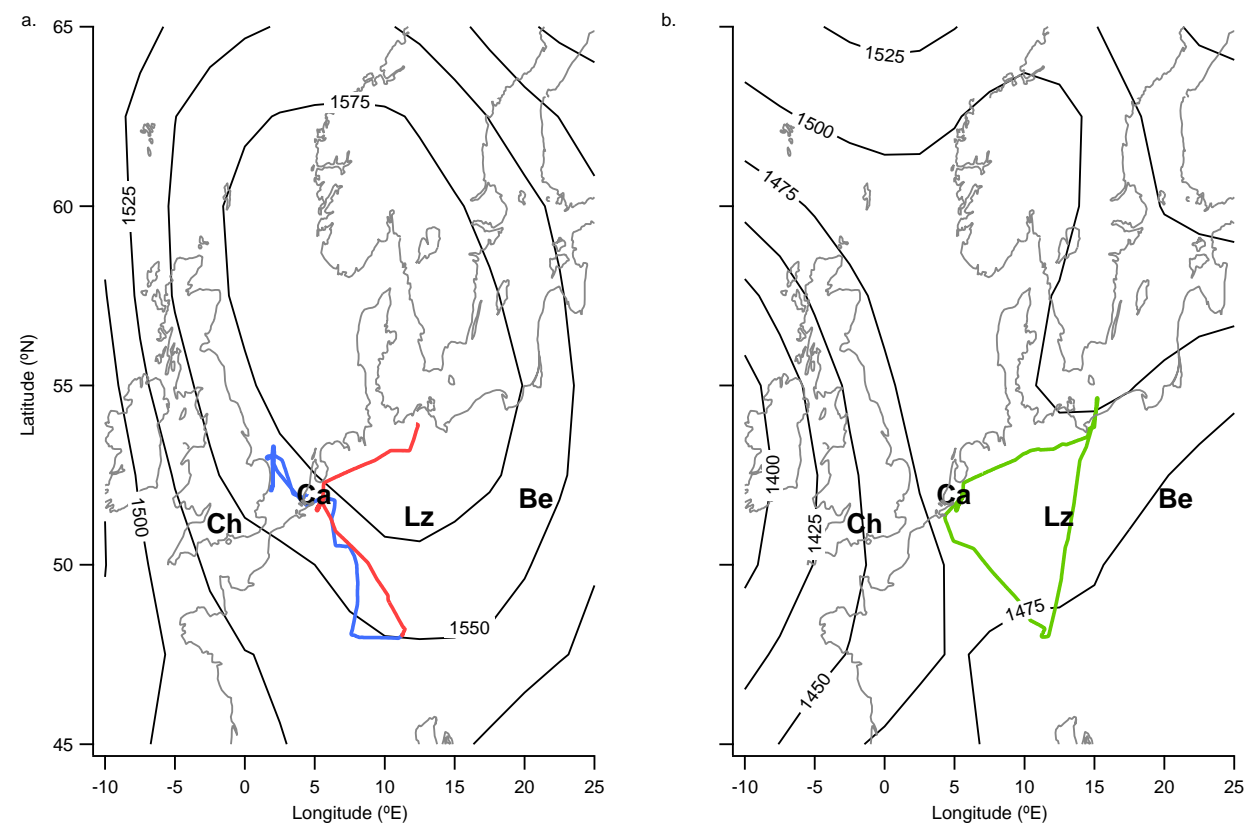

Fig. 1. Flight tracks of the BAe-146 considered by this analysis. Also shown are ECMWF 850 hPa geopotential height fields. Panel (a) displays the flight tracks for B362 (6 May 2008, blue track) and B366 (8 May 2008, red track) and the geopotential height field is from 12:00 UTC on 6 May 2008. Panel (b) displays the flight track for B379 (21 May 2008, green track) and the geopotential height field is from the same date at 12:00 UTC. AERONET stations relevant to this study are marked, including Chilbolton (Ch), Cabauw (Ca), IFT-Leipzig (Lz) and Belsk $(\mathrm{Be})$.

described previously (e.g. Osborne et al., 2007; Haywood et al., 2008), thus only a brief summary and specific details pertinent to this study are described here.

The PSAP measures the absorption coefficient at $567 \mathrm{~nm}$ via monitoring the rate of decay of light transmission due to accumulation of absorbing particles upon a filter. Several corrections to the PSAP absorption coefficient are required (Bond et al., 1999). These include misinterpretation of scattering as absorption by purely scattering particles and overestimation of the absorption coefficient as a result of multiple scattering at the filter fibers. Furthermore, recent analyses (Cappa et al., 2008; Lack et al., 2008) have identified significant enhancement of the PSAP absorption signal that is correlated with high organic aerosol loadings, although no attempt is made in this study to account for any such enhancements.
The nephelometer system onboard the BAe-146 comprises two separate instruments operating in series. Scattering coefficients were corrected for angular truncation and nonlambertian light source errors assuming sub-micron aerosol dominated the scattering following the procedure presented by Anderson and Ogren (1998). The first nephelometer measures the sample aerosol in a "dry" condition. The system does not use an active drying method, rather it relies on inlet ram heating and the increase in temperature in the cabin to reduce the humidity in the sample. This is usually sufficient to obtain "dry" Relative Humidity (RH) values in the range of $20-40 \%$. The aerosol sample is then passed through a controlled humidifier, which cycles between a 40-90\% RH range prior to being sampled by the second instrument in order to measure the scattering coefficient as a function of RH. This allows derivation of the hygroscopic scattering enhancement, 
Table 2. Summary of instrumentation from the ground-based site at Cabauw and the BAe-146 aircraft used in this study. Acronyms used are as follows: cToF-AMS (compact Time-of-Flight Aerosol Mass Spectrometer, HR-ToF-AMS (High-Resolution Time-of-Flight Aerosol Mass Spectrometer), Single Particle Soot Photometer (SP2), PSAP (Particle Soot Absorption Photometer), MAAP (Multi-Angle Absorption Photometer) and PCASP (Passive Cavity Aerosol Spectrometer Probe). The wavelengths and size ranges applicable to the optical and physical property measurements are given in brackets.

\begin{tabular}{lll}
\hline Measurement & Cabauw & BAe-146 \\
\hline Composition & HR-ToF-AMS & cToF-AMS, SP2 \\
Scattering coefficient & Nephelometer $(450,550,700 \mathrm{~nm})$ & Nephelometer $(450,550,700 \mathrm{~nm})$ \\
Absorption coefficient & MAAP $(670 \mathrm{~nm})$ & PSAP $(567 \mathrm{~nm})$ \\
Size distribution & N/A & PCASP $(0.1-3 \mu \mathrm{m})$ \\
\hline
\end{tabular}

$f(\mathrm{RH})$, to be determined. The mean $f(\mathrm{RH})$ growth curve from each flight was used to calculate the ambient scattering coefficient by combining the dry nephelometer measurements with the measured ambient RH. Additional details regarding corrections to the nephelometer data are included in Appendix B.

At the Cabauw ground-based site, a single threewavelength nephelometer identical to the instruments operated on the BAe-146 sampled dry aerosol and was operated alongside a Thermo model 5012 Multi-Angle Absorption Photometer (MAAP Petzold et al., 2005), which measures the aerosol absorption coefficient at $670 \mathrm{~nm}$. The nephelometer underwent the same corrections as the BAe-146 version for angular truncation and non-lambertian source errors. Both the MAAP and PSAP absorption coefficients were converted to the reference wavelengths of the nephelometer assuming a $1 / \lambda$ wavelength dependence, which is consistent with urban derived aerosol where the absorption is dominated by black carbon (e.g. Kirchstetter et al., 2004; Bond and Bergstrom, 2006). Furthermore, no significant influence by biomass burning or mineral dust was present for these case studies, both of which are the major contributors to increased absorption wavelength dependence (i.e. exceeding the $1 / \lambda$ wavelength dependence). These could then be combined with the nephelometer measurements to calculate the aerosol extinction coefficient and the single scattering albedo, $\omega_{0}$.

\subsection{Aerosol Mie scattering calculations}

The experimental data alone cannot be used to separate the sensitivities of the aerosol scattering to changes in chemical composition and uptake of water vapour, so in order to estimate this, a Mie scattering model is employed to explore this sensitivity.

A Mie scattering code (Edwards and Slingo, 1996) was used to calculate the scattering due to aerosols at a wavelength of $550 \mathrm{~nm}$ based upon measured aerosol chemical and physical properties measured onboard the aircraft. The Mie code calculates scattering, absorption and phase function for a given aerosol mass based on its size distribution, bulk density and refractive index. In this case, the dry number-size distributions from the PCASP below $1 \mu \mathrm{m}$ were used. Dry bulk density and refractive index were estimated using volume mixing of the component refractive indices and densities of the individual constituent aerosol components (summarised in Table 3) based upon the AMS and SP2 measurements. While such assumptions can prove quantitatively problematic (e.g. Oshima et al., 2009), we include the calculations in order to explore the sensitivity of atmospheric aerosol to changes in aerosol chemical composition, which includes the addition of water at high relative humidity.

In order to calculate the scattering coefficient in a fully humidified atmosphere, the contribution of hygroscopic water uptake to the bulk size distribution, refractive index and density of the aerosol must be calculated. The bulk hygroscopic growth factor of the aerosol mass was estimated by combining the individual growth factors of the constituent aerosol components at the required relative humidity using a ZSR mixing rule approach (Zdanovskii-Stokes-Robinson, Stokes and Robinson, 1966; Gysel et al., 2007; Swietlicki et al., 2008). The growth factors of the inorganic components (ammonium nitrate and ammonium sulphate) were parameterised based upon the work of Tang (1996), while BC was assumed to have a growth factor equal to unity. The hygroscopicity of the organic component was assumed to be consistent with that of Suwanee river fulvic acid using the treatment from Brooks et al. (2004). Fulvic acid was assumed to be representative of the relatively aged-oxidised nature of the OM encountered in this study, as it has chemical functionalities that are representative of aged OM (e.g. McFiggans et al., 2005). The volume of water taken up by the aerosol was then calculated based upon calculation of a humidified size distribution produced by applying the hygroscopic growth factor to the dry PCASP size distribution. Hygroscopic growth was assumed to occur uniformly across the entire size range, with no change in number density. A humidified bulk density and refractive index was then estimated by incorporating the physical and optical properties of water into the aerosol volume mixing calculation. Further details regarding this approach and its application to the entire LONGREX dataset will be included in a future manuscript in the EUCAARI Special Issue. 
Table 3. Summary of the individual component densities and refractive indices used in this study. The numbers in brackets refer to the study referenced for the associated parameter value, which are as follows: [1] Weast (1985), [2] Penner et al. (1998), [3] Alfarra et al. (2006), [4] Bond and Bergstrom (2006), [5] Toon et al. (1976) and [6] Dinar et al. (2008).

\begin{tabular}{lcc}
\hline Aerosol component & Density $\left(\mathrm{kgm}^{-3}\right)$ & Refractive index \\
\hline Ammonium nitrate & $1725[1]$ & $1.60-0 \mathrm{i}[1]$ \\
Ammonium sulphate & $1769[2]$ & $1.53-0 \mathrm{i}[5]$ \\
Organic matter & $1400[3]$ & $1.63-0.021 \mathrm{i}[6]$ \\
Black carbon & $1800[4]$ & $1.95-0.79 \mathrm{i}[4]$ \\
\hline
\end{tabular}

\section{Overview of conditions in North-Western Europe during May 2008}

In order to set the measurements over Cabauw in the context of the larger scale spatial distribution of Aerosol Optical Depth (AOD), data from several AERONET stations is shown in Fig. 2a from the high pressure period of LONGREX from the 6-14 May 2008. The latter days of the campaign i.e. when B379 took place are not shown as the temporal coverage was poor at some of the stations, particularly at Leipzig. The locations of the AERONET stations are approximately orientated west-to-east (shown in Fig. 1) in order to examine the impact of the large scale synoptic situation upon the AOD distribution. The AOD increased as a function of longitude from east-to-west, ranging from median values of 0.13 in Belsk to 0.30 at Chilbolton. The stations in North-Western Europe, Cabauw and Chilbolton, regularly exceeded the 95 th percentile value $(0.32)$ observed at Leipzig, indicating that there was a significant gradient in the aerosol fields between these locations.

Figure $2 \mathrm{~b}$ displays a histogram of daily averaged AOD measurements for both May 2008 and all of 2008 at Cabauw. AOD values at Cabauw were typically below 0.2 on approximately $50 \%$ of the days with available measurements during all of 2008. The level 2.0 AERONET product is used which is cloud-screened, thus the meausurements are biased towards clearer sky periods and Spring/Summer (AprilSeptember). During May 2008, there were no AOD events below 0.1 , with $16 \%$ of the days having daily averaged values from $0.1-0.2$. The proportion of days where the AOD was between $0.2-0.3(35 \%)$ was greatly enhanced compared with the long-term measurements (24\%). Furthermore, there were a greater proportion of events at even larger AOD values compared with the annual statistics. These results indicate that May 2008 was a particularly polluted period compared with the rest of 2008 .
For additional context in terms of the aerosol chemical composition, measurements from the HR-Tof-AMS at the ground-based site at Cabauw are shown in Fig. 3. The measurements presented correspond to the periods when the BAe-146 operated in the vicinity of Cabauw. A key feature of these periods is the dominance of the OM component over the nitrate component, particularly during daytime hours. A Positive Matrix Factorisation (PMF, Paatero, 1997; Paatero and Tapper, 1994) analysis of the organic mass spectra measured by the HR-ToF-AMS at Cabauw was conducted using the principles introduced by Ulbrich et al. (2009). The resolved PMF components were interpreted based upon their similarity to reference mass spectra and correlations with external time series (Mensah, 2010). The nomenclature used follows the framework adopted by Jimenez et al. (2009), which is consistent with the procedures used in Morgan et al. (2010). The PMF analysis revealed four major components; Hydrocarbon-like Organic Aerosol (HOA), SV-OOA and two LV-OOA type factors (Mensah, 2010). The SV-OOA time series shown in Fig. 3 displays similar trends to the nitrate time series, which is a common observation due to their semi-volatile nature. Furthermore, the SV-OOA component is typically less than the combined LV-OOA components.

Also shown are two radiosonde profiles of temperature and RH from days when the aircraft operated in the vicinity of Cabauw. These highlight the well-mixed nature of the atmospheric boundary layer, with the ambient temperature profile closely following the adiabatic lapse rate and the $\mathrm{RH}$ profile peaking at the top of the boundary layer at approximately $2000 \mathrm{~m}$. The well-mixed nature of the boundary layer over continental Europe was a key feature of the flights in this region.

The well-mixed nature of the boundary layer could also be determined from the aircraft operations. This is illustrated by Fig. 4 which shows the thermodynamic structure and its influence upon the aerosol concentration and composition from flight B362. The flight consisted of a sequence of Straight and Level Runs (SLRs) between 500-2000 m altitude heading north-westwards over continental Europe, followed by several lower level SLRs and profiles down to approximately $100 \mathrm{~m}$ over the North Sea off the eastern coast of the UK. Figure $4 \mathrm{~b}$ displays the relationship between the wet equivalent potential temperature and the total water content. A relatively linear relationship between these two properties indicates a water vapour-wet equivalent potential temperature mixing line, which was predominantly the case for most of the flight. The main divergence from this simple linear relationship corresponded to the low-level SLR-8 over the North Sea at approximately $100 \mathrm{~m}$ altitude, where a layer of much moister air was encountered. The mass-size distribution measured by the AMS during SLR-8 is shown in Fig. 4d, which shows that the aerosol was strongly enriched in ammonium nitrate and $\mathrm{OM}$ and that considerable amounts were present at large sizes (the largest particles are likely to be less efficiently transmitted through the aerodynamic lens, thus the 

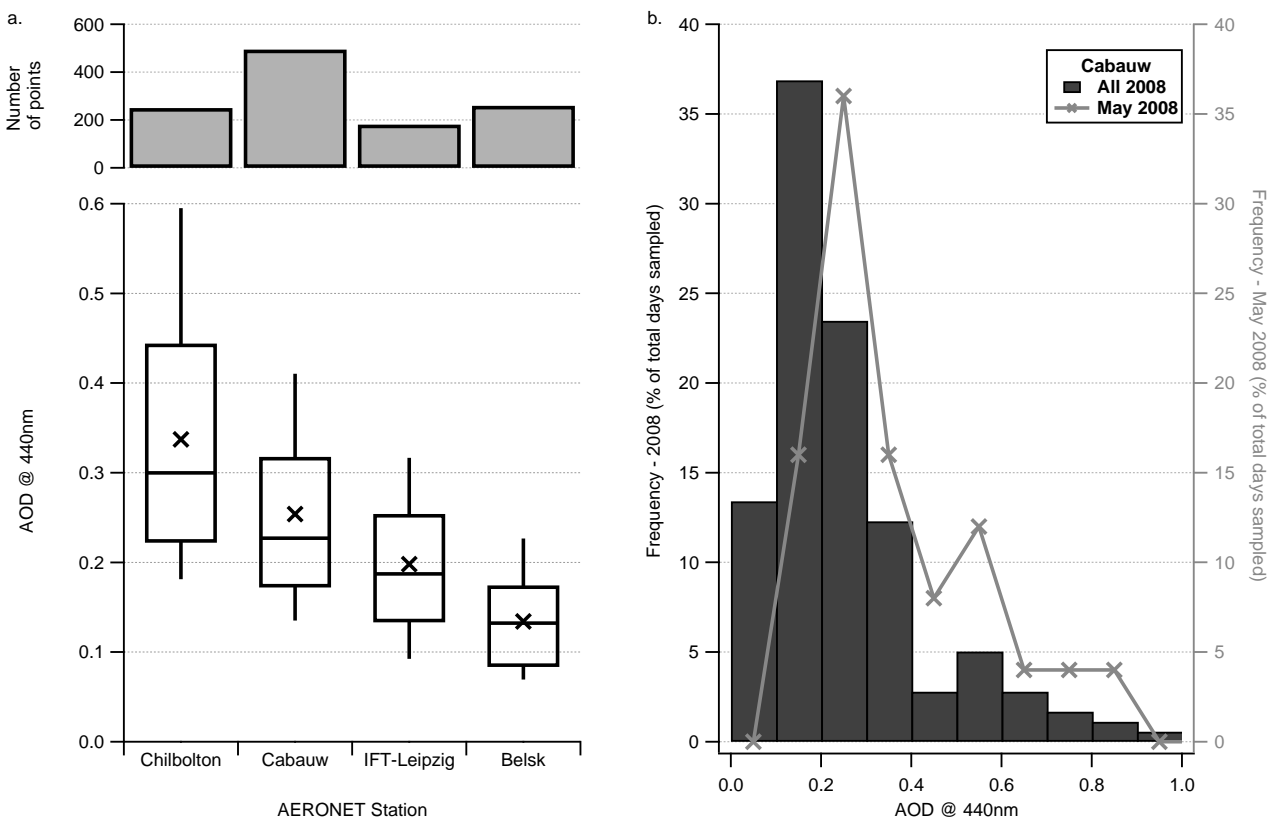

Fig. 2. Panel (a) displays boxplot summary statistics for AOD derived from AERONET stations in Northern Europe during the LONGREX high pressure period (6-14 May 2008). Crosses represent the mean value, while horizontal lines represent the 25th, 50th and 75th percentiles. The whiskers represent the 5th and 95th percentiles. Panel (b) displays a histogram of daily mean AOD at Cabauw for the year 2008 (left axis) and May 2008 (right axis). The values are normalised to the total number of days sampled in each case, which equaled 179 for the year 2008 and 25 for May 2008.
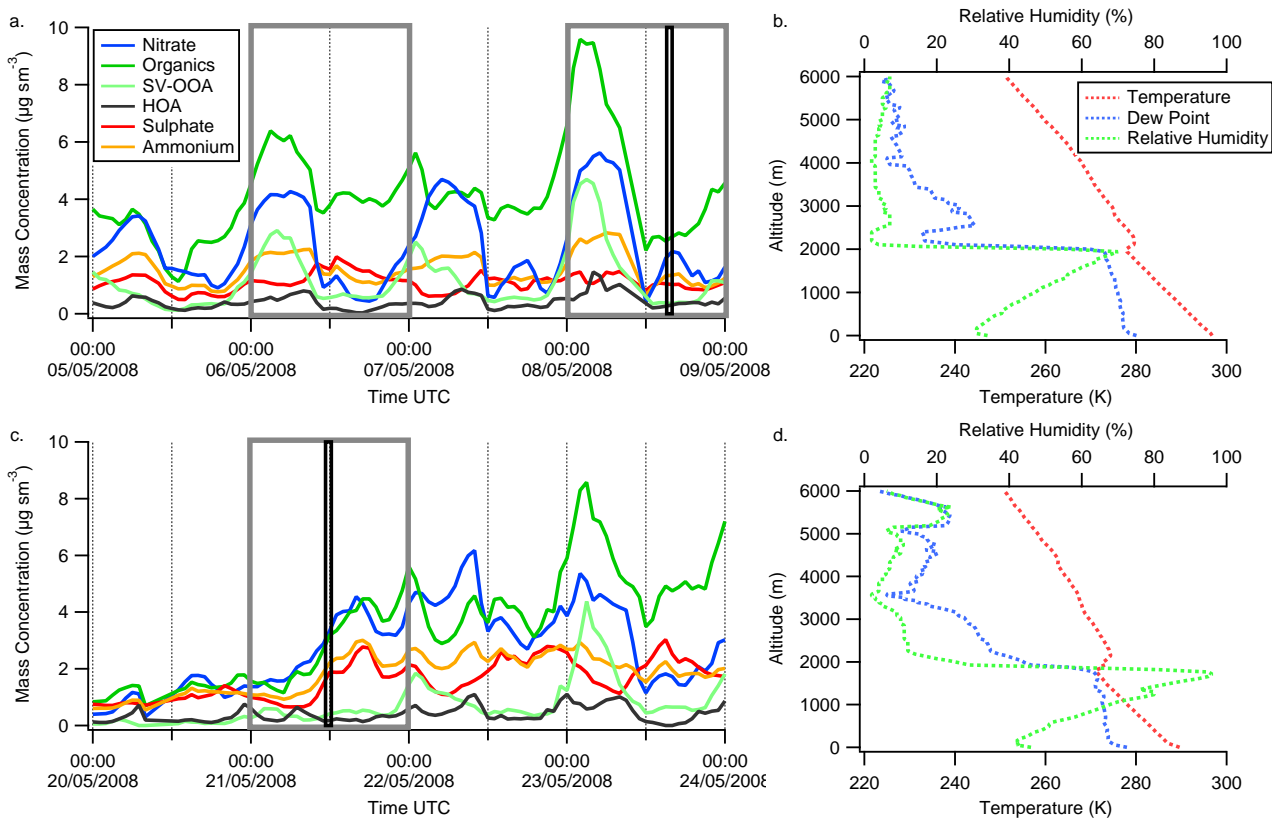

Fig. 3. Panels (a) and (c) display time series of AMS mass concentrations from Cabauw from 5-9 May 2008 and 20-24 May 2008, respectively. The Semi-Volatile Oxygenated Organic Aerosol (SV-OOA) and Hydrocarbon-like Organic Aerosol (HOA) components are also shown. The grey boxes indicate days when the BAe-146 conducted flight operations in the vicinity of Cabauw, while the black boxes indicate the time periods when the BAe-146 was within $50 \mathrm{~km}$ of Cabauw during B366 and B379. Panels (b) and (d) display the temperature and relative humidity profiles derived from radiosonde launches from Cabauw at 16:04 UTC on 8 May 2008 and 12:01 UTC on 21 May 2008 respectively. 

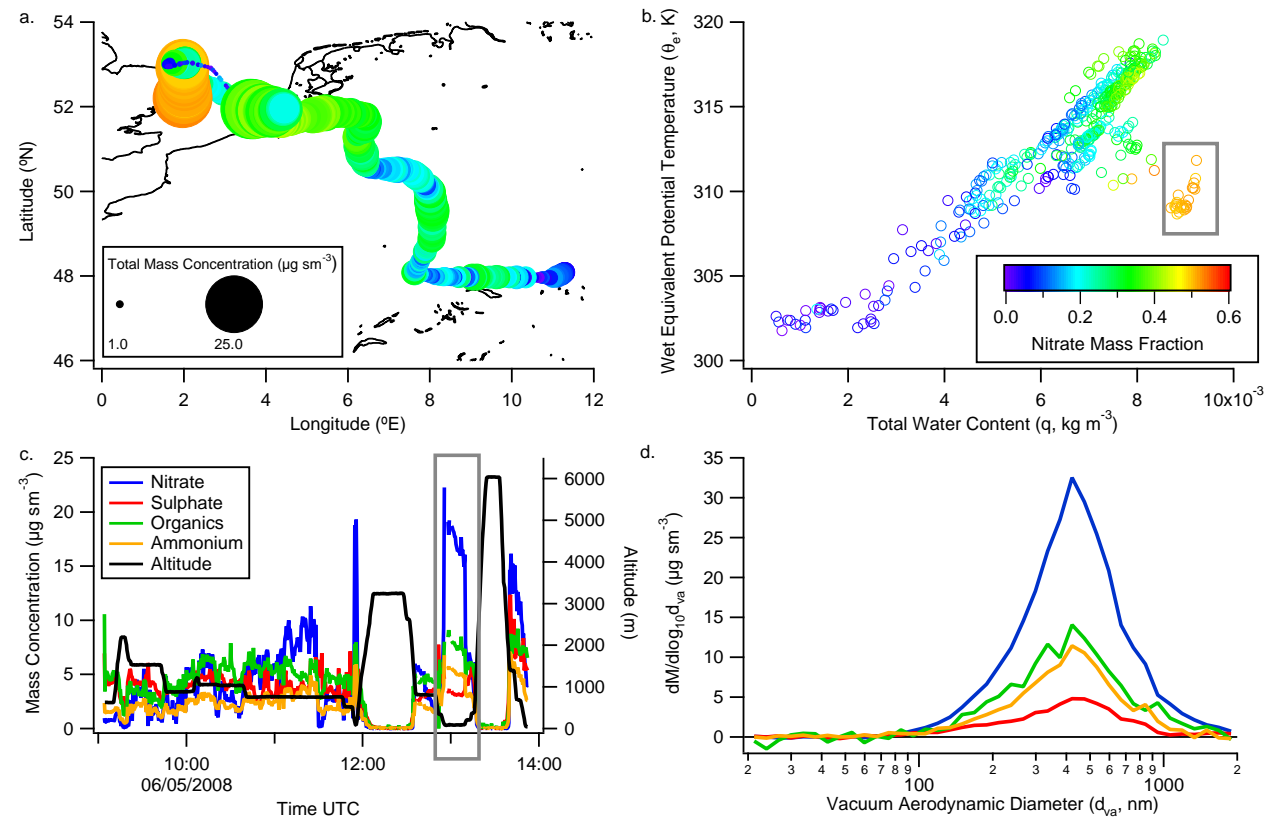

Fig. 4. Case study example of the vertical mixing of atmospheric aerosol during flight B362. Panel (a) displays the aircraft's flight track coloured according to the nitrate mass fraction, while the markers are sized according to the AMS total mass concentration. Panel (b) shows the relationship between the wet equivalent potential temperature, $\theta_{e}$, and the total water content, $q$. The relationship is coloured according to the nitrate mass fraction, while the grey box indicates the data corresponding to SLR-8 during B362. Panel (c) shows the AMS mass concentration time series and the altitude of the aircraft during the flight. Panel (d) shows the mass-size distribution from the AMS for SLR-8.

concentrations reported in such instances are likely an underestimate). These shallow-moist layers over the ocean surface were consistently observed during the study, with associated enhancements in aerosol concentrations. The points are coloured according to the nitrate mass fraction, defined as the fractional contribution of nitrate to the total mass concentration derived from the AMS. Over continental Europe, enhanced nitrate mass fractions and increased sub-micron aerosol concentrations were associated with increases in potential temperature. This phenomenon is indicative of vertical mixing of air parcels within the boundary layer. During the flight, nitrate is either approximately equal to or enhanced relative to the OM, unlike the surface observations at Cabauw where the OM component is greater than the nitrate component.

\section{Vertical distribution of aerosol chemical composition}

The vertical variation in the aerosol chemical composition is presented in Fig. 5 from flights B366 and B379. Both flights consisted of SLRs between 600-2000 m altitude from eastto-west across Northern Germany and the Netherlands with short "saw-tooth" profiles in order to probe the vertical variability. Both incorporated a series of SLRs at different altitudes upwind of the ground-site at Cabauw and are charac- terised by significant sub-micron aerosol loadings. These revealed a clear increasing gradient in total aerosol mass from east-to-west, which was predominantly driven by increasing $\mathrm{OM}$ and ammonium nitrate concentrations (see Morgan et al., 2010, for a more detailed discussion). Flight B366, whose flight track is shown in Fig. 5a, indicated that there is significant variability in the concentrations of the $\mathrm{OM}$ and ammonium nitrate. Nitrate concentrations ranged from 2 $12 \mu \mathrm{g} \mathrm{sm}^{-3}$ in the vicinity of Cabauw, while OM concentration ranged from $2-5 \mu \mathrm{g} \mathrm{sm}^{-3}$. Concentrations of nitrate and $\mathrm{OM}$ at the ground-site at Cabauw during this period were approximately $2-2.5 \mu \mathrm{g} \mathrm{sm}^{-3}$ each. The second example is from B379, whose flight track is shown in Fig. 5c. The nitrate concentration exceeded that of the OM component on the aircraft, while at the surface the concentrations were approximately equal. The nitrate concentration at the surface was $3-4 \mu \mathrm{g} \mathrm{sm}^{-3}$, while aloft the concentrations regularly exceeded $6 \mu \mathrm{g} \mathrm{sm}^{-3}$. Additionally, the OM concentration was enhanced aloft compared with the ground-based measurements.

The vertical distribution of aerosol chemical composition from B366 during the SLRs in the vicinity of Cabauw is summarised in Fig. 6a. SLRs are used as the vertical profiles during the flights were relatively short compared to the AMS sampling frequency ( $30 \mathrm{~s})$, thus if profiles were shown then very few data points would be included. B379 is not 

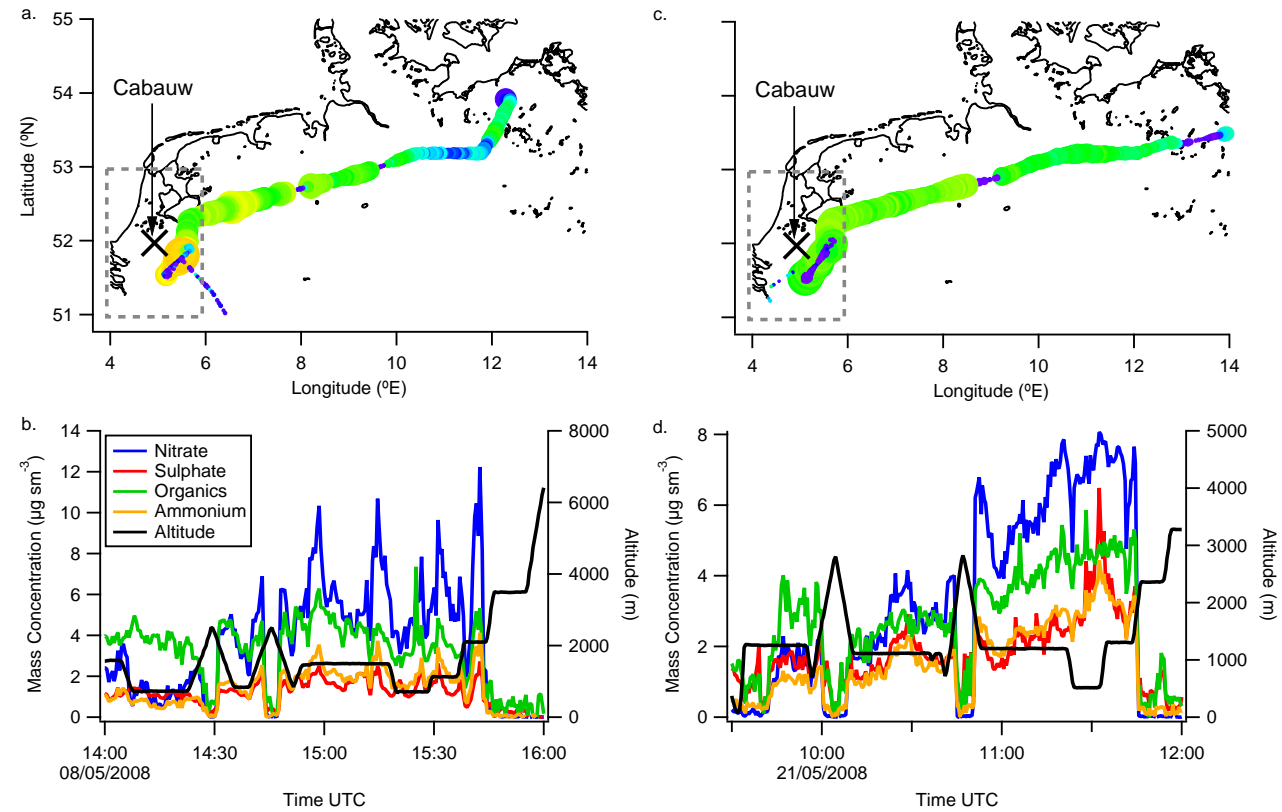

Fig. 5. Case study example of the distribution of aerosol chemical composition from B366 and B379. Panel (a) displays the B366 flight track coloured according to the nitrate mass fraction, while the markers are sized according to the AMS total mass concentration. The same colourscale and marker size is used as Fig. 4. Panel (b) shows the B366 AMS mass concentration time series and the altitude of the aircraft during the flight. Panel (c) shows the flight track for B379. Panel (d) shows the B379 AMS mass concentration time series and the altitude track of the BAe-146. The grey boxes in panels (a) and (c) mark out the boundaries of the defined proximity to Cabauw in the main text.
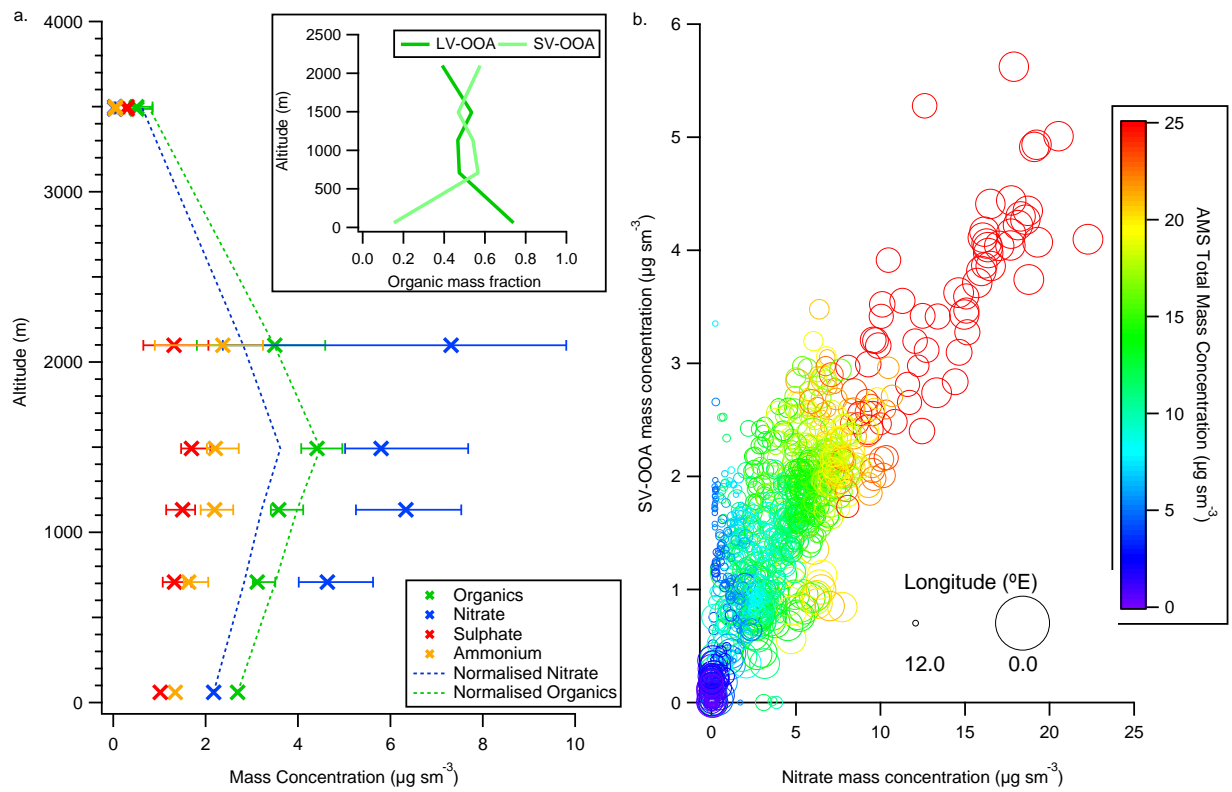

Fig. 6. Case study example of the vertical distribution of aerosol chemical composition. Panel (a) displays the AMS mass concentrations as a function of height from SLRs in the vicinity of Cabauw during flight B366, where the markers indicate the median concentration and the horizontal bars represent the 25 th and 75 th percentiles. The points at the lowest altitude correspond to the concentrations from a groundbased AMS at Cabauw. The hashed lines represent the normalised nitrate and organic profiles when they are scaled to the change in sulphate with height relative to the ground-based measurement. The inset panel displays the altitude dependence of the Low-Volatility Oxygenated Organic Aerosol (LV-OOA) and the Semi-Volatile Oxygenated Organic Aerosol (SV-OOA) organic mass fractions. Panel (b) displays the relationship between the SV-OOA component and nitrate for B362, B366 and B379. The markers are coloured according to the AMS total mass concentration and sized by longitude. 

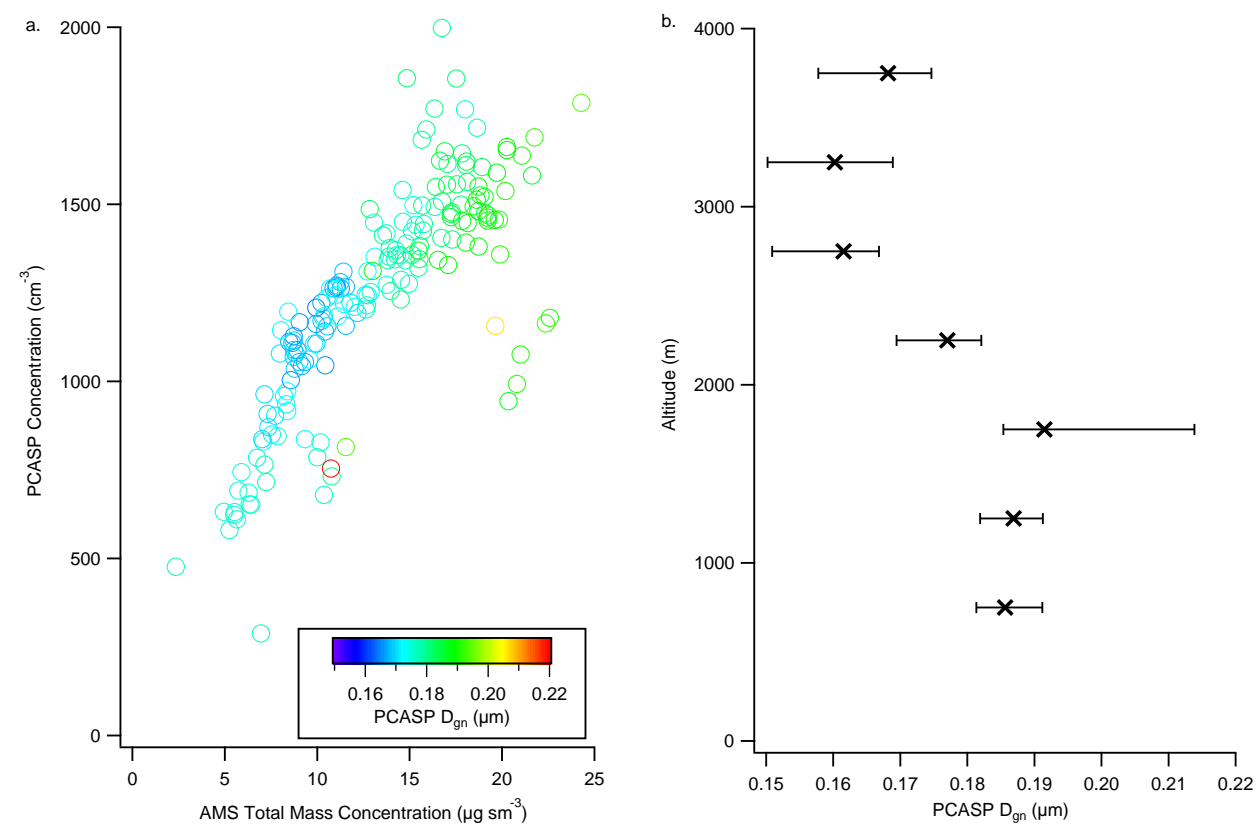

Fig. 7. Relationship between aerosol microphysical properties and total mass concentration from the AMS. Panel (a) displays the relationship between the sub-micron aerosol number concentration from the PCASP instrument with total AMS mass concentration. The points are coloured according to the sub-micron geometric mean diameter. Panel (b) shows the sub-micron geometric mean diameter derived from the PCASP measurements as a function of height when averaged over SLRs. The crosses refer to the median geometric diameter, while the horizontal bars represent the 25 th and 75 th percentiles.

shown as the SLRs had reduced vertical coverage compared with B366. Comparison with the AMS measurements from the ground site indicated that the total mass concentration was enhanced aloft. The nitrate mass fraction increased with altitude and was the dominant chemical component, while at the ground, the OM component dominated. Furthermore, there was an increasing gradient in the OM concentration up to approximately $1500 \mathrm{~m}$ relative to the ground, while the absolute concentration exceeded the surface OM concentration up to approximately $2000 \mathrm{~m}$. The LV-OOA mass concentration was relatively constant throughout the boundary layer and was very similar to the sulphate profile. Consequently, the increase in the OM was dominated by an increase in the SV-OOA component. The significant variability in the concentrations, as indicated by the large inter-quartile range at each altitude for nitrate and $\mathrm{OM}$, was a consequence of vertical mixing. As the aircraft operated at a constant altitude over each SLR, the air mass sampled switched between surface originating air and mid-tropospheric air, modulating the aerosol concentrations accordingly. The SLRs typically range from at least 10-30 data points i.e. approximately 5-15 minutes sampling time. The SLR at $2100 \mathrm{~m}$ for example contained 11 data points. During B379, the mass concentrations for nitrate and OM were again elevated relative to the ground. Median nitrate concentrations of $6.9 \mu \mathrm{g} \mathrm{sm}^{-3}$ and $7.3 \mu \mathrm{g} \mathrm{sm}^{-3}$ at $500 \mathrm{~m}$ and $1300 \mathrm{~m}$ respectively were observed, while the OM median concentrations were 4.5 and $4.7 \mu \mathrm{g} \mathrm{sm}^{-3}$. This compared with ground-based AMS measured values from $2.8-3.4 \mu \mathrm{g} \mathrm{sm}^{-3}$ for nitrate and $2.7-3.2 \mu \mathrm{g} \mathrm{sm}^{-3}$ for OM during this period.

Figure $6 \mathrm{~b}$ displays the strong association between the SVOOA component and nitrate that existed in these polluted examples of flight operations in North-Western Europe. The markers in Fig. $6 \mathrm{~b}$ are sized according to the longitude of the aircraft, which indicates that the association between SVOOA and nitrate increases in Western Europe.

Figure 7 displays the relationship between the aerosol chemical composition and the aerosol physical properties by comparing the AMS with the PCASP instrument during B379 (the PCASP was not functioning during B366). Figure 7a shows that as the aerosol mass concentration increased, the sub-micron number concentration measured by the PCASP increased, as does the mean geometric diameter of the aerosol. Thus the number concentration measured by the PCASP increases as more particles are present in the size range measured by the PCASP i.e. above $100 \mathrm{~nm}$. This shift in the mean size displays an altitude dependence, which is shown in Fig. 7b, with a greater mean size towards the top of the boundary layer. 


\section{Aerosol optical properties}

\subsection{Aerosol scattering coefficient}

Figure 8 displays the relationship between the ambient scattering coefficient and total aerosol mass concentrations observed on the aircraft, which shows a strong coupling between them. The observed variability in the total mass concentration is driven predominantly by ammonium nitrate, with additional input from the SV-OOA in these cases.

To investigate the effect of the increase in semi-volatile components and the associated additional water on the optical properties as a function of height, we have compared the aircraft measurements made throughout the depth of the boundary layer, with the optical properties of the aerosol based upon the observations at the ground, extrapolated throughout the depth of the boundary layer. No additional particle mass was added to the ground based aerosol measurements with height but the aerosol were allowed to increase in size due to additional water condensation at higher humidities. This is accomplished using the following procedure:

1. Extract and average the scattering and absorption data that is coincident with the BAe-146 overpasses.

2. Assume that the number, mass and chemical composition of the particulate as measured at the ground are representative of the entire depth of the well-mixed boundary layer.

3. Calculate the ambient scattering vertical profile by assuming that this is equal to the scattering at the ground plus the additional water uptake as a function of increasing relative humidity, which is calculated from the $f(\mathrm{RH})$ measurements from the aircraft and the $\mathrm{RH}$ data from the radiosonde launches.

4. Assume that the absorption coefficient is not dependent upon $\mathrm{RH}$ and that the value is uniform throughout the boundary layer, which is consistent with the airborne and ground-based measurements.

5. Combine the estimated ambient scattering and absorption profiles to estimate the total extinction profile, which in turn can be used to estimate the AOD.

6. Calculate the average ambient $\omega_{0}$ through the boundary layer column.

The above were estimated for boundary layer aerosol based upon the radiosonde data and the aerosol measurements from the BAe-146 during B366 and B379. The estimated ambient scattering profiles based upon the Cabauw data are shown in Fig. 9. Vertical profiles are used rather than SLRs as the nephelometer measurements from the aircraft have a time resolution of $1 \mathrm{~s}$, which allows the vertical gradients to be more easily captured while minimising the

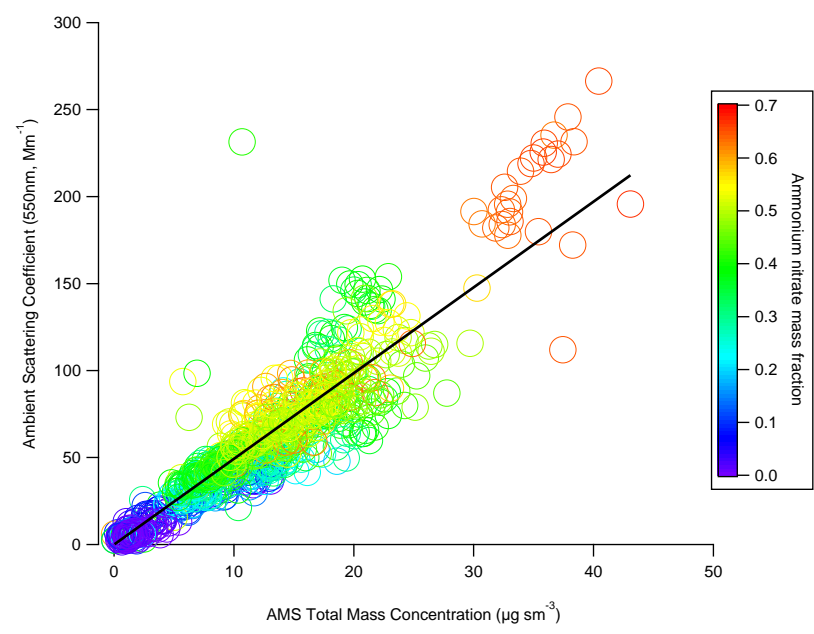

Fig. 8. Relationship between ambient light scattering and the total mass concentration derived from the AMS on the BAe-146. The solid black line indicates the slope of the linear regression analysis, which corresponds to an ambient mass scattering efficiency of $4.93 \mathrm{~m}^{2} \mathrm{~g}^{-1}$. The points are coloured according to the ammonium nitrate mass fraction.

impact of horizontal gradients upon the comparison with the ground. Also shown is the in-situ measured scattering from the aircraft when it operated in the vicinity of Cabauw. This shows that the scattering profile is entirely consistent with the chemical composition data, with strong enhancements relative to the ground-based measurements and an increasing gradient with height. This strong enhancement is particularly clear in Fig. 8, which demonstrates that the increased measured scattering is strongly associated with increased aerosol mass and that this is consistent with increased ammonium nitrate concentrations. The dry scattering coefficient measured by the nephelometer has an uncertainty estimate of $10 \%$ (Anderson et al., 1996). When comparing the dry scattering coefficient profile from the aircraft with the ground-based measurements, the airborne measurements are generally above this uncertainty and are consistent with the increased dry aerosol mass measured by the AMS. Some datapoints from B366 fall within the $10 \%$ band due to variability in the vertical domain closer to the surface and at the very top of the boundary layer.

The results indicate that there is a clear enhancement in the scattering coefficient when comparing between the in-situ measurements from the aircraft and those estimated based on the ground-based values. Also shown in Fig. 9a is the HSRL extinction profile observed from the DLR Falcon which took place shortly before the BAe-146 operations in the vicinity of Cabauw. The HSRL extinction profile follows the same general structure as the BAe-146, although the HSRL profile is averaged over a relatively short period in comparison to the BAe-146 measurements thus it does not exhibit the same variability. In Fig. 9b, the HSRL extinction profile 

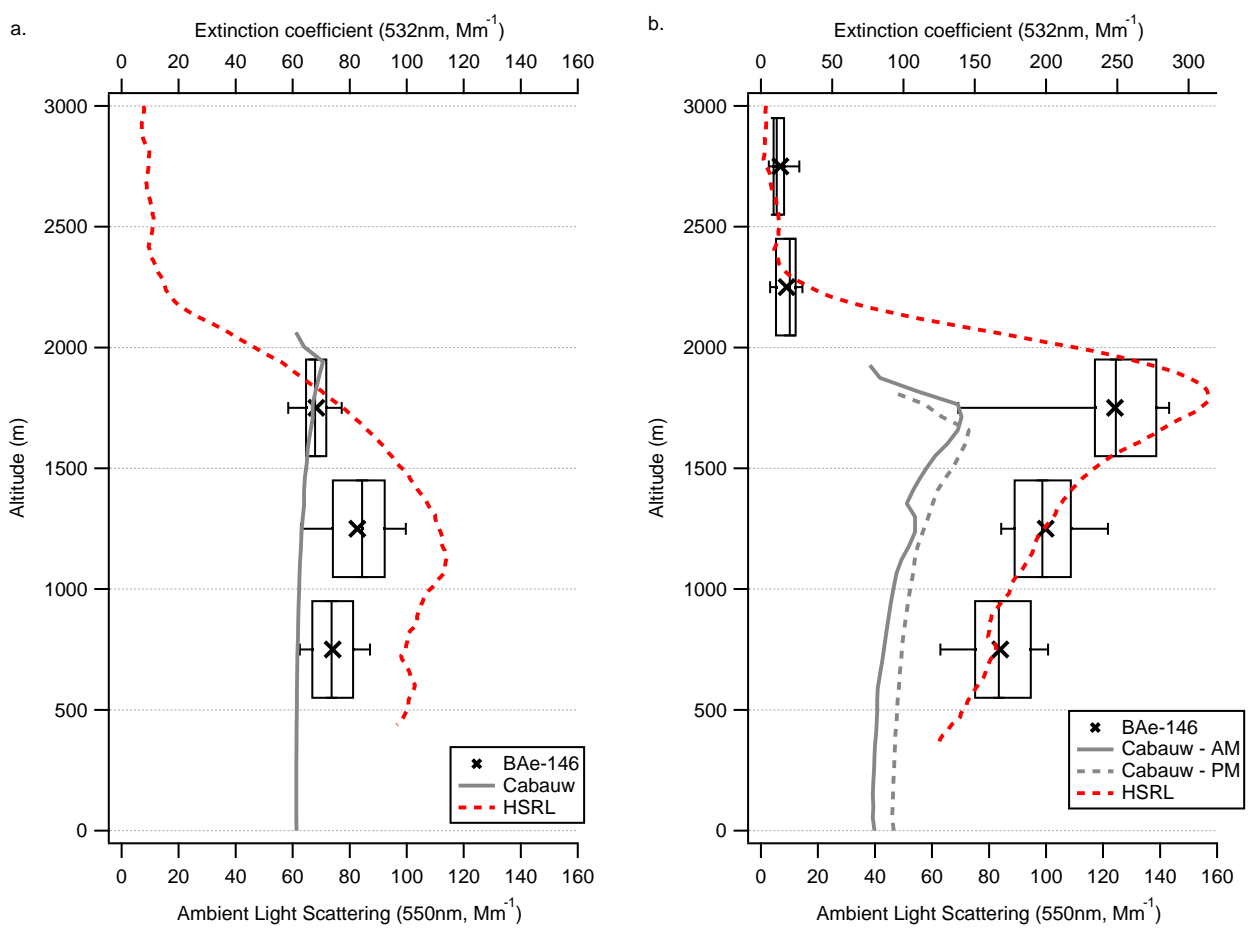

Fig. 9. Boxplot summary statistics for the measured ambient scattering profile from the BAe-146 in the vicinity of Cabauw for (a) B366 and (b) B379. Crosses represent the mean value, while horizontal lines represent the 25th, 50th and 75th percentiles. The whiskers represent the 5th and 95th percentiles. Also shown is the measured ambient scattering from the ground site at Cabauw, which is extrapolated to derive an estimated scattering profile based upon the method described in Sect. 5.1. In (a) the extinction profile from the HSRL onboard the DLR Falcon is also shown from 14:44-14:56 UTC. In (b) the extinction profile from the HSRL is shown for 13:46-13:54 UTC. Note that the scale for the nephelometer measurements and the HSRL are different in (b).

shown is from several hours after the BAe-146 measurements. The HSRL extinction profile was approximately a factor of 2 greater than the measured profile from the BAe146 earlier in the day. This is consistent with the advection of more polluted air over the ground site between the BAe146 and HSRL measurement periods, which can be seen in Fig. 3. Nevertheless, the general vertical structure and main features are very similar. Also shown in Fig. $9 b$ is the estimated scattering profile based on the Cabauw ground-based measurements during the HSRL measurements. Again there is considerable enhancement in the measured scattering profile versus the estimated scattering profile in this instance.

The relatively modest enhancement for B366 compared to B379 between $1500-2000 \mathrm{~m}$ is likely a result of differences in the thermodynamic structure observed by the aircraft and the radiosonde at the top of the boundary layer. The aircraft measurements indicate that the $\mathrm{RH}$ is beginning to reduce below $2000 \mathrm{~m}$, which is consistent with the extinction profile from the HSRL, whereas for the radiosonde ascent, the RH does not begin to reduce until slightly above this level. For B379, the thermodynamic structure measured by the radiosonde ascent and the aircraft are in excellent agreement, thus the scattering profiles display similar vertical structure.

\subsection{Aerosol optical depth and single scattering albedo}

The AOD and $\omega_{0}$ values derived from the aircraft measurements were compared with the estimated values from the ground-based data assuming that the extinction below $500 \mathrm{~m}$ is equal to the estimated extinction based upon the groundbased in-situ measurements, as the aircraft was unable to sample below that level. The results from B366 and B379 are summarised in Table 4.

For B366, the AOD calculated from the aircraft measurements was enhanced relative to the ground-based estimate above the 50th percentile level, with increased AOD values of $14-21 \%$. The AOD calculated from the airborne measurements is in good agreement with the HSRL, which measured average AOD values of $0.21 \pm 0.05$. At the lower percentile values, the aircraft values are comparable to the ground-based estimate. For B379, the AOD at the $50^{\text {th }}$ percentile level is enhanced by $80 \%$, while at the 75 th percentile, the AOD measured on the aircraft was double that estimated from the ground. The increase in scattering aloft also caused a moderate change in $\omega_{0}$ due to the enhanced scattering contribution to the total extinction. 
Table 4. Summary of optical properties for flight B366 and B379 when comparing between the measurements from the BAe-146 and estimated values based upon the ground-based measurements from Cabauw. The Aerosol Optical Depth (AOD) is calculated using the ambient scattering coefficient and the corresponding absorption value from $0-2 \mathrm{~km}$. $\omega_{0}$ refers to the average single scattering albedo for the vertical column from $0-2 \mathrm{~km}$. RF refers to the calculated negative radiative forcing based upon the AOD, $\omega_{0}$ and the surface albedo $\left(R_{S}\right)$ values used. The solar constant is normalised by the cosine of the solar zenith angle $\left(56^{\circ}\right.$ during this period for B 366 and $32^{\circ}$ for $\left.\mathrm{B} 379\right)$ in order to account for the sun's location not being directly overhead.

\begin{tabular}{llcccccc}
\hline Flight & Parameter & Cabauw $(550 \mathrm{~nm})$ & \multicolumn{5}{c}{ BAe-146 $(550 \mathrm{~nm})$} \\
& & Mean & 5th & 25th & 50 th & 75th & 95th \\
\hline B366 & AOD & 0.14 & 0.13 & 0.14 & 0.16 & 0.16 & 0.17 \\
& $\omega_{0}$ & 0.92 & 0.91 & 0.92 & 0.93 & 0.93 & 0.93 \\
& RF $\left(R_{S}=0.16\right)$ & 1.35 & 1.19 & 1.35 & 1.63 & 1.63 & 1.73 \\
& RF $\left(R_{S}=0.26\right)$ & 0.67 & 0.53 & 0.67 & 0.89 & 0.89 & 0.95 \\
B379 & AOD & 0.10 & 0.14 & 0.17 & 0.18 & 0.20 & 0.21 \\
& $\omega_{0}$ & 0.93 & 0.94 & 0.95 & 0.95 & 0.96 & 0.96 \\
& RF $\left(R_{S}=0.16\right)$ & 2.34 & 3.45 & 4.40 & 4.66 & 5.42 & 5.69 \\
& $\operatorname{RF}\left(R_{S}=0.26\right)$ & 1.28 & 2.03 & 2.76 & 2.92 & 3.59 & 3.77 \\
\hline
\end{tabular}

The AOD from the aircraft measurements was also calculated at $450 \mathrm{~nm}$ in order to compare with corresponding AERONET measurements at $440 \mathrm{~nm}$. The AOD for the entire vertical column was not estimated from the ground-based measurements as these only refer to the boundary layer contribution as the measurements do not reflect aerosol properties in the free troposphere. The AERONET AOD corresponds to the total vertical column, while the BAe-146 measurements refer to the aerosol profile below $7500 \mathrm{~m}$ and $8500 \mathrm{~m}$ for B366 and B379 respectively, as this was the maximum altitude achieved by the aircraft in the vicinity of Cabauw. The AOD contribution below the operating height of the aircraft was estimated from the ground-based measurements. The results of this comparison are shown in Table 5 and indicate that $70-80 \%$ of the observable extinction was located within the boundary layer. The results for the AERONET AOD values are within the range of values measured by the BAe-146, although the aircraft measurements are biased somewhat lower compared with the AERONET AOD. This could be a consequence of some upper layers which were not observed by the aircraft, which is potentially consistent with the HSRL data which indicated an increasing gradient with altitude at $8000 \mathrm{~m}$. Furthermore, estimated ambient scattering based upon the airborne nephelometer measurements may be underestimated when more hygroscopic aerosol components, such as ammonium nitrate, contribute to the majority of the aerosol mass. This is a consequence of using the mean hygroscopic growth curve measured by the wet nephelometer. This would lead to an under-prediction of the ambient scattering and hence the AOD.

\subsection{Aerosol water uptake}

The Mie scattering code was used to investigate the importance of aerosol water uptake based upon measured size distributions and aerosol chemical composition, which was
Table 5. Summary of Aerosol Optical Depth (AOD) values for flights B366 and B379. The values derived from the column integrated measurements from the BAe-146 and AERONET are compared. The BAe-146 data corresponds to the vertical column above Cabauw up to $7500 \mathrm{~m}$ for B366 and $8500 \mathrm{~m}$ for B379. The percentage values reported in brackets below the BAe-146 values represent the approximate fraction of the AOD located below $2000 \mathrm{~m}$. The AERONET values are the total column integrated values.

\begin{tabular}{ccccc}
\hline Flight & \multicolumn{3}{c}{ BAe-146 (450 nm) } & AERONET (440 nm) \\
& 5 th & 50 th & 95 th & Mean \\
\hline B366 & 0.20 & 0.26 & 0.34 & 0.35 \\
& $(95 \%)$ & $(85 \%)$ & $(74 \%)$ & \\
B379 & 0.23 & 0.33 & 0.44 & 0.44 \\
& $(83 \%)$ & $(76 \%)$ & $(68 \%)$ & \\
\hline
\end{tabular}

used to estimate aerosol water uptake based upon ZSR calculations, from SLRs during B379. Experiments were also conducted for dry aerosols, with agreement to within $30 \%$ compared with the measured dry scattering coefficient values. Comparison between ambient scattering estimates based upon the nephelometer measurements and the Mie calculated values yielded typical agreement to within $50 \%$ for $\mathrm{RH}$ values below $75 \%$. For run 5, where the average RH was $80 \%$, the Mie scattering value was close to a factor of 2 greater than the estimate based upon the nephelometer measurements. Such a discrepancy could occur due to a multitude of reasons, which result from the assumptions applied to estimate both the ambient scattering from the nephelometer measurements and the Mie scattering calculations. As mentioned in Sect. 5.2, the water uptake by more hygroscopic aerosol components was likely underestimated, which would apply in this case as ammonium nitrate represented greater than $50 \%$ of the aerosol mass for run 5 . The sampling efficiency 
of the nephelometer may also be reduced when larger particles (at enhanced relative humidity) are introduced. The simplified assumption of uniform hygroscopic growth across an internally mixed aerosol for the Mie calculations is liable to introduce some uncertainty in the Mie ambient scattering.

Mie calculations as a function of $\mathrm{RH}$ were used to explore the effect of water uptake by ambient aerosols by comparing the relative change in scattering with increasing ammonium nitrate and water content. The calculations are used to explore the theoretical sensitivity of the increase in scattering associated with enhanced ammonium nitrate content and the scattering due to additional water uptake. The apparent overestimation when comparing the Mie ambient scattering with the measured values suggests that the analysis will yield the maximum likely effect. Two experiments were undertaken; one where ammonium nitrate was assumed to have a growth factor of unity and a second where the literature values for ammonium nitrate detailed in Tang (1996) were used. By comparing these two experiments, the impact of additional scattering associated with water from the increasing ammonium nitrate mass could be estimated by examining the relative increase in scattering between the two experiments. Each SLR was used as input to the Mie code using a range of relative humidities. Figure 10 summarises the percentage increase in scattering by water associated with ammonium nitrate by comparing the two experiments for each SLR. The SLRs are ordered by increasing ammonium nitrate mass concentration/fraction. At low concentrations and mass fractions of ammonium nitrate, the impact is slight. As the mass fraction and concentration increases, the scattering enhancement due to water uptake increases strongly. The relative increases are most dramatic at the greatest relative humidities. At $70 \% \mathrm{RH}$, increasing the ammonium nitrate mass fraction from $25 \%$ (SLR 1) to $50 \%$ (SLR 3) increases the enhancement from $16 \%$ to $36 \%$. At $90 \% \mathrm{RH}$, the enhancement increases from $42 \%$ to $112 \%$.

\subsection{Aerosol radiative forcing}

Aside from the nature of the underlying surface, the AOD, $\omega_{0}$ and aerosol backscatter fraction terms govern the magnitude and sign of the direct radiative forcing by aerosols. This is shown in Eq. (1) from Haywood and Shine (1995), which defines the aerosol induced perturbation in the upward radiation flux at the Top-Of-Atmosphere (TOA) as:

$$
\begin{aligned}
& \Delta_{a} F \uparrow=\frac{1}{2} F_{T} T^{2}\left(1-A_{c}\right) \cdot\left[\omega_{0} \bar{\beta}_{a}\left(1-\bar{R}_{s}\right)^{2}\right. \\
& \left.\quad-2\left(1-\omega_{0}\right) \bar{R}_{s}\right] \mathrm{AOD}
\end{aligned}
$$

The TOA forcing, $\Delta_{a} F \uparrow$, is estimated using the respective values from the aircraft and the ground site. The common terms for both scenarios in Eq. (1) are the solar constant, $F_{T}$, equal to $1366 \mathrm{Wm}^{-2}$, the atmospheric transmittance, $T$, equal to 0.76 , the cloud fraction, $A_{c}$ and the surface albedo, $R_{s}$. The solar constant value is weighted by the cosine of

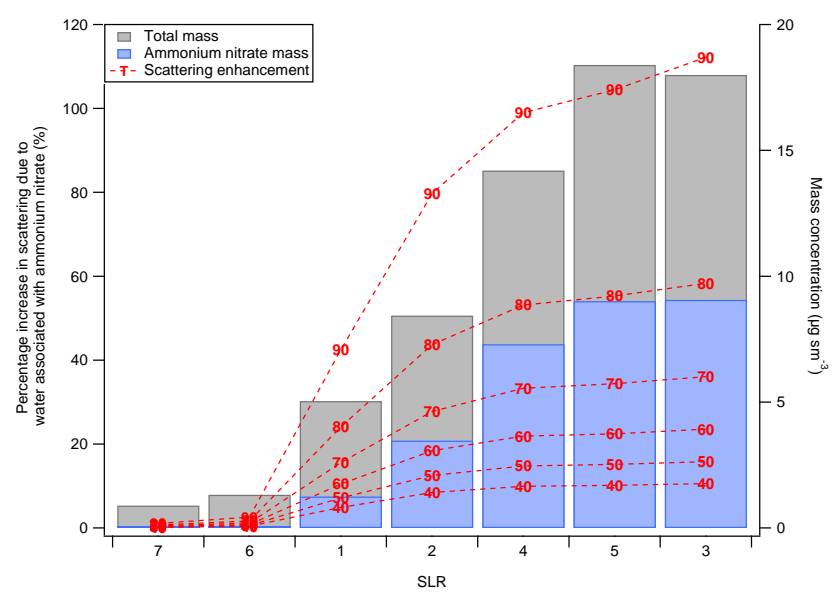

Fig. 10. Summary of the enhancement in aerosol scattering due to water uptake by ammonium nitrate aerosol derived from the Mie calculations. The text markers and hashed line refer to the percentage increase in scattering by water associated with ammonium nitrate over a relative humidity range from $40-90 \%$. The Straight and Level Runs (SLRs) are from B379 and are ordered by increasing ammonium nitrate mass concentration or mass fraction. Also shown is the average total mass and ammonium nitrate concentrations for each of the SLRs.

the solar zenith angle in order to account for the location of Cabauw and the time of day when the measurements took place. The surface albedo is assumed to be representative of grassland values with an albedo from 0.16-0.26. We calculated the aerosol backscatter fraction, $\beta_{a}$, using the nephelometer measurements. The average backscatter fraction at Cabauw was 0.14 , while on the aircraft an average value of 0.16 was calculated for both B366 and B379. A value of 0.16 was applied for the radiative forcing calculations as the impact is small (less than $30 \%$ for greater $R_{S}$ values) compared with changes in AOD and $\omega_{0}$. The radiative forcing is estimated assuming cloud-free conditions, where $A_{c}$ is zero, which results in a maximum forcing estimate.

The results are summarised in Table 4 and indicate that the direct radiative forcing is strongly enhanced when comparing the in-situ boundary layer airborne measurements with the ground-based derived values. For B366, the enhancement ranged from $21-33 \%$ at the 50th percentile level depending upon the surface albedo. For B379, the radiative forcing estimate was always greater based on the aircraft estimate with an enhancement greater than a factor of two at the 50th percentile level. Compared with the strong changes in the AOD, the $\omega_{0}$ enhancements are relatively modest, thus the major changes in radiative forcing are dominated by changes in AOD rather than $\omega_{0}$ for the case studies presented. 


\section{Discussion}

\subsection{Enhancement of semi-volatile material}

The ground-based AMS data indicated that during the periods considered, significant pollution loadings were present in North-Western Europe, with sub-micron aerosol loadings largely exceeding $10 \mu \mathrm{g} \mathrm{sm}^{-3}$ in daytime conditions. A consistent feature of the results presented in Sect. 4 is the enhanced sub-micron particulate concentrations aloft measured on the BAe-146 compared to the ground-site at Cabauw. The increase was primarily a consequence of enhanced ammonium nitrate and OM concentrations. The median nitrate concentration increased by 2.0-3.4 times that of the ground based value, while the median OM concentration was increased by a factor of up to 1.6. The median sulphate concentration measured on the aircraft was between 1.3-1.7 times that of the surface concentration, while the lower range of values sampled by the aircraft were similar to the sulphate concentrations on the ground. At the surface the OM component was generally either greater or equal to the nitrate concentration when the aircraft was operating close to the ground site. Furthermore, the aircraft data showed that the nitrate mass fraction had a positive gradient with increasing height within the boundary layer. The combined aircraft and ground-based data showed that the sulphate concentration was relatively uniform, with a slight enhancement observable in the aircraft data. Additionally, the PCASP data indicated that the mean diameter of the aerosol increased with altitude within the boundary layer. All of the observations were consistent with semi-volatile aerosol species condensing onto pre-existing aerosol, which results in an increase in the mean diameter of the aerosol.

The fact that the sulphate concentration measured on the aircraft is somewhat greater than the value measured at the ground was likely a consequence of imperfect vertical or horizontal mixing. In order to account for such potential inhomogeneities, the observed increase in the sulphate profile was used to calculate a normalised nitrate and organic profile by multiplying the ground-based values by the observed increase in sulphate. The results of this normalisation are shown on Fig. 6a, which indicates that the observed increase in the nitrate concentration is far in excess of the normalised nitrate profile. The median OM profile is very similar to the normalised OM profile, which suggests that the more modest increase in OM may be a result of imperfect mixing. However, the factor analysis indicates that the chemical nature of the OM changes with height, with the SV-OOA component increasing with altitude in the boundary layer. The results show that the observed increase in particle mass with altitude in the boundary layer was predominately driven by ammonium nitrate.

These comparisons between the ground-based and aircraft AMS instruments suggest that the increase in the mass of nitrate is well above the uncertainty limit for AMS mass con- centration measurements (approximately 25\%, Canagaratna et al., 2007), while the median and $75^{t h}$ percentile sulphate concentrations are within these bounds. The changes in OM are close to the uncertainty limit at the median level, although the concentrations exceed this limit at the 75th percentile.

These chemical and physical observations of the aerosol vertical distribution are consistent with semi-volatile partitioning of gas-phase precursors to the particle phase. Ammonium nitrate and SV-OOA were strongly associated and increased with altitude, suggesting that semi-volatile partitioning predominantly drove the enhanced particulate mass aloft. In terms of the OM burden, this is consistent with recent frameworks which have proposed that the entire OM component should be treated as semi-volatile (Donahue et al., 2006; Robinson et al., 2007). Thus, adiabatic cooling and mixing of semi-volatile organic precursors could combine to produce enhanced SOA concentrations. Coincident with the reduction in temperature is the enhanced $\mathrm{RH}$ at the top of the boundary layer, which further favours partitioning to the particle phase. Such examples indicate the strong impact of the thermodynamic structure of the boundary layer upon both the concentration and composition of the aerosol burden.

\subsection{Impact of semi-volatile aerosol components upon the radiative budget}

The partitioning of semi-volatile components to the particle phase has significant implications for the radiative budget during the pollution episodes presented. Given that the partitioning behaviour occurs at elevated levels within the boundary layer, where the RH is increased, the aerosol extinction will be further enhanced due to additional water uptake. This is evident from the relationship between the ambient scattering coefficient and total aerosol mass concentrations discussed in Sect. 5 and in Fig. 8. A key feature was that when the ammonium nitrate mass fraction was low, the total mass concentration was also reduced which in turn decreased the level of scattering by the aerosol burden. Thus the partitioning of semi-volatile aerosol precursors contributed significantly to the AOD during major pollution episodes where sub-micron aerosol concentrations were enhanced. While the SV-OOA concentration increased during such periods, such increases were generally smaller than the increases in ammonium nitrate concentration, which was often 3-4 times that of SV-OOA. Thus the majority of the increased scattering and AOD was driven by changes in the ammonium nitrate concentration.

On the basis of the B379 case study, strong enhancements in scattering were associated with increased ammonium nitrate concentrations and mass fractions. Measured increases in the ammonium nitrate mass fraction from $25 \%$ to $50 \%$, yielded a factor of two increase in dry scattering measured by the nephelometer. Compared with the estimated AOD based upon the ground-based measurements, enhancements of up to $100 \%$ at the 75 th percentile level were observed based 
upon the airborne measurements, which translated to a more than doubling of the associated radiative forcing when taking into account the increase in $\omega_{0}$ also. On the basis of Mie calculations, increases in the ammonium nitrate mass fraction resulted in major increases in aerosol water uptake. This, in addition to the increased dry mass of the aerosol, dramatically increased the scattering coefficient higher in the boundary layer where the RH was greatest. The Mie calculations underline the importance of these observations, as they illustrate the importance of the enhancement of ammonium nitrate in an area of increased relative humidity.

An important observation when comparing the two case studies was that the scattering enhancement was greater for the B379 case study relative to the B366 case study. Examination of the temperature and $\mathrm{RH}$ profiles showed that the B379 case study was both colder and moister than the B366 case study, which is again consistent with an increased contribution from semi-volatile components aloft. This is similar to the modelling results presented by Morino et al. (2006), where a colder and moister atmosphere increased the particle mass higher in the boundary layer relative to the ground. Furthermore, the enhanced RH will increase the water uptake by the ammonium nitrate dominated aerosol mass, as shown by the Mie calculations.

Compared with the 2008 annual frequency distribution of AOD at Cabauw, May 2008 included 24\% of the days where daily averaged AOD values exceeded 0.2. Consequently, the studies in May 2008 are representative of a significant pollution episode in North-Western Europe. Furthermore, the observed increase in AOD from east-to-west was consistent with the spatial gradients in aerosol composition shown in Figs. 5 and 6 and the overview of aerosol concentration and composition presented in Morgan et al. (2010). These demonstrated that ammonium nitrate and OM concentrations reached a maximum in North-Western Europe during the period studied. We have demonstrated that such conditions are exacerbated by the partitioning of semi-volatile precursors to the particle phase, causing a large increase in the aerosol direct radiative forcing.

In terms of future climate scenarios and accompanying aerosol radiative forcing, North-Western Europe may represent an analogue for other highly polluted regions affected by substantial agricultural emissions. Significant reductions in $\mathrm{SO}_{2}$ have occurred in recent years (Monks et al., 2009), which diminishes the role of sulphate aerosol but increases the availability of ammonia to form ammonium nitrate. Such reductions in $\mathrm{SO}_{2}$ are also likely to occur in other polluted regions in future (e.g. Pinder et al., 2007). Thus an inability to accurately model semi-volatile compounds is likely to be a significant deficiency in attempts to constrain the direct radiative forcing by aerosols.

\section{Conclusions}

A case study comparing the aerosol chemical composition measured from two platforms operating during highly polluted conditions in North-Western Europe has been presented. This revealed an increase in secondary aerosol mass as a function of altitude in the boundary layer. Specifically, airborne in-situ measurements in the vicinity of a groundbased measurement site at Cabauw, Netherlands, showed that ammonium nitrate was the dominant chemical component aloft, while at the ground OM dominated. Furthermore, the fractional contribution to the sub-micron aerosol mass of ammonium nitrate increased with height in the boundary layer. This was primarily attributed to partitioning of semi-volatile gas phase precursors to the particle phase at reduced temperature and enhanced $\mathrm{RH}$, a phenomenon which has been observed previously in California (Neuman et al., 2003), Tokyo (Morino et al., 2006) and the UK region (Morgan et al., 2009). In addition to the increase in ammonium nitrate, the OM component also increased with height in the boundary layer. The results of a factor analysis of the aircraft and ground-based AMS measurements show that the enhancement in the OM component was dominated by SV-OOA. This is consistent with gas-to-particle conversion of semivolatile organic precursors, in a similar manner to the ammonium nitrate system. Consequently, partitioning of semivolatile species can produce significant additional inorganic and organic particulate mass.

By comparing the optical properties measured on the aircraft with coincident measurements from the ground, a strong enhancement in the AOD was shown to occur. This was coupled with an increase in the single scattering albedo also. This directly translated to a significant perturbation of the radiative balance of the atmospheric column in the region. An enhancement of the direct radiative forcing by aerosols greater than $100 \%$ was observed when taking into account the additional mass, associated water uptake and hence scattering caused by the partitioning phenomenon. The hygroscopic properties of ammonium nitrate in particular were shown to cause significant increases in aerosol scattering based upon Mie calculations. Such increases in AOD and radiative forcing have major implications for regional weather and climate, particularly as semi-volatile compounds are often not included in global and regional aerosol models (e.g. Myhre et al., 2006). Consequently, the radiative impact of anthropogenic aerosols is likely to be severely underestimated in Northern Europe, where ammonium nitrate and $\mathrm{OM}$ are major components of the sub-micron aerosol burden. Such underestimations are liable to be greatest during major pollution episodes. The periods identified by this study present an ideal opportunity to test regional and global climate model representations of this anthropogenically perturbed region. 


\section{Appendix A}

\section{Size-resolved aerosol chemical composition}

Morgan et al. (2010) did not include information regarding the derivation of size-resolved chemical composition from the AMS on the BAe-146, thus this is included here. The particle time-of-flight measurement through the AMS vacuum chamber is dependent upon the supersonic expansion of a particle as it enters the vacuum chamber. Particle diameter $\left(D_{\text {va }}\right)$ is related to particle velocity $\left(v_{p}\right)$ via application of the following equation from Allan et al. (2003):

$v_{p}=\frac{L_{c}}{t_{p}}=\frac{v_{g}-v_{l}}{1+\left(D_{\mathrm{va}} / D^{*}\right)^{b}}+v_{l}$

where $L_{c}$ is the particle flight length, $t_{p}$ is the particle time of flight, $v_{g}$ is the gas velocity on exiting the nozzle, $v_{l}$ is the gas velocity within the aerodynamic lens and $D^{*}$ and $\mathrm{b}$ are experimentally determined calibration constants. The AMS on the BAe-146 did not use a constant pressure inlet system, thus a change in the ambient pressure will modulate the lens pressure, affecting the particle time-of-flight measurement. A reduction in ambient pressure will shift the transmission function of the lens to smaller sizes. Such a change will impact the mass measurement if the aerosol size distribution is markedly different to that of the lens transmission. In order to account for this, a pressure-dependent size calibration was performed following the principle detailed by Bahreini et al. (2003). This entailed varying the inlet pressure from 1000 $\mathrm{hPa}$ and $500 \mathrm{hPa}$, while Polystyrene Latex Spheres (PSLs) of known size, shape and density are introduced into the AMS in order to assess the affect of altitude upon the determined particle size. A pressure dependent form of Eq. (A1) presented by Crosier et al. (2007) is then used to determine particle diameter:

$v_{p}=\frac{\left(v_{g}^{\prime}+v_{g}^{\prime \prime} P_{l}\right)-\left(v_{l}^{\prime}+v_{l}^{\prime \prime} P_{l}\right)}{1+\left(D_{\mathrm{va}} /\left(D^{* \prime}+D^{* \prime \prime} P_{l}\right)\right)^{\left(b^{\prime}+b^{\prime \prime} P_{l}\right)}}+\left(v_{l}^{\prime}+v_{l}^{\prime \prime} P_{l}\right)$

where $P_{l}$ is the line pressure of the AMS and $v_{g}^{\prime}, v_{g}^{\prime \prime}, v_{l}^{\prime}, v_{l}^{\prime \prime}$, $D^{*^{\prime}}, D^{*^{\prime \prime}}, b^{\prime}$ and $b^{\prime \prime}$ are experimentally determined coefficients. The predicted particle velocity was derived using a multivariate fit based on each particle size at each sample pressure and is shown in the supplementary material section. The coefficients were as follows: $v_{g}^{\prime}=106.22, v_{g}^{\prime \prime}=0.36876$, $v_{l}^{\prime}=151.236, \quad v_{l}^{\prime \prime}=-0.027345, \quad D^{*^{\prime}}=101.9, \quad D^{*^{\prime \prime}}=-0.079133$, $b^{\prime}=0.9479$ and $b^{\prime \prime}=-0.00045891$.

\section{Appendix B}

\section{Nephelometer corrections}

On the BAe-146, the inlet system prior to the nephelometers and PSAP is not actively dried; instead the sample is dehydrated as a result of ram heating upon entering the inlet system. Consequently, the sample RH is known to vary as a function of the ambient $\mathrm{RH}$, sometimes reaching more than $60 \%$ when the ambient RH exceeds approximately $95 \%$. In order to account for these fluctuations, the following empirical formula from Carrico et al. (2003) was used to express the hygroscopic response of the aerosol sample:

$f(\mathrm{RH})=1+a\left(\frac{\mathrm{RH}_{\mathrm{wet}}}{100}\right)^{b}$

where $f(\mathrm{RH})$ refers to the ratio of the "wet" scattering coefficient, $\sigma_{w}$ and the "dry" scattering coefficient, $\sigma_{d}, \mathrm{RH}_{\text {wet }}$ refers to the RH of the "wet" nephelometer and $a$ and $b$ are fit coefficients. Only data from Straight and Level Runs (SLRs) when the 'dry' nephelometer's RH was less than $40 \%$ was used, which eliminates erroneous $f(\mathrm{RH})$ measurements due to a change in the RH of the "dry" nephelometer. Fits were derived for each flight in order to account for any variations in size and composition. This information was then applied to the "dry" nephelometer data above $40 \% \mathrm{RH}$ in order to generate corrected nephelometer data, $\sigma_{\mathrm{cd}}$ at a reference $\mathrm{RH}$ of $40 \%$ using the following equation:

$\sigma_{\mathrm{cd}}=\sigma_{d}\left(1+a\left(\frac{\mathrm{RH}_{\mathrm{dry}}}{100}\right)^{b}\right)$

where $\mathrm{RH}_{\text {dry }}$ is the desired reference $\mathrm{RH}$ for the corrected nephelometer data. The $f(\mathrm{RH})$ curves can then be recalculated using a consistent reference $\mathrm{RH}$ across all of the data. The calculated fit coefficients, $a$ and $b$, are then used to approximate the ambient scattering coefficient, $\sigma_{\mathrm{amb}}$, using the following modified form of Eq. (B2):

$\sigma_{\mathrm{amb}}=\sigma_{\mathrm{cd}}\left(1+a\left(\frac{\mathrm{RH}_{\mathrm{amb}}}{100}\right)^{b}\right)$

where $\mathrm{RH}_{\mathrm{amb}}$ is the measured ambient $\mathrm{RH}$.

Further potential uncertainties in the nephelometer scattering coefficients may arise due to water uptake at high relative humidity e.g. at values above $85 \%$. Larger particles may grow above $1 \mu \mathrm{m}$ at sufficient $\mathrm{RH}$, which would invalidate the correction coefficients applied to the "wet" nephelometer. The $f(\mathrm{RH})$ response was also tested by comparing the ratio of the uncorrected "dry" and "wet" nephelometers and negligible differences were found at high RH values. Water uptake will also lower the refractive index of the aerosol sample (Massoli et al., 2009) and introduce an error in the $f(\mathrm{RH})$ determination when using the Anderson and Ogren (1998) truncation corrections as they are sensitive to the assumed refractive index. Massoli et al. (2009) estimate a 2\% error, which is within the experimental error for the system. Consequently, we have not included a correction for changes in the refractive index. 
Acknowledgements. This work is supported by Natural Environment Research Council (NERC) ADIENT project NE/E011101/1, EUCAARI project 036833-2 and EUSAAR contract 026140 . W. T. Morgan was supported by NERC studentship NER/S/A/2006/14040 and a CASE sponsorship from Aerodyne Research Inc. The NERC National Centre for Atmospheric Science (NCAS) Facility for Ground based Atmospheric Measurements (FGAM) supported the maintenance of the cToF-AMS. NCAS also supported the development of the data interpretation methods employed here through its Composition Directorate. Thanks to the Cabauw IMPACT team for provision of the radiosonde data. We thank G. de Leeuw, the principal investigator at the AERONET station at Cabauw for the provision of the AOD data and the principal investigators at the other AERONET sites used. We also thank F. Abicht, A. Minikin, T. Hamburger and A. Stohl for their major contributions to the project. We thank the FAAM, the Met Office, Avalon, DLR-Falcon and DirectFlight personnel for their contributions to the campaign.

Edited by: A. Wiedensohler

\section{References}

Alfarra, M. R., Paulsen, D., Gysel, M., Garforth, A. A., Dommen, J., Prévôt, A. S. H., Worsnop, D. R., Baltensperger, U., and Coe, H.: A mass spectrometric study of secondary organic aerosols formed from the photooxidation of anthropogenic and biogenic precursors in a reaction chamber, Atmos. Chem. Phys., 6, 52795293, doi:10.5194/acp-6-5279-2006, 2006.

Allan, J. D., Jimenez, J. L., Williams, P. I., Alfarra, M. R., Bower, K. N., Jayne, J. T., Coe, H., and Worsnop, D. R.: Quantitative sampling using an Aerodyne aerosol mass spectrometer: 1. Techniques of data interpretation and error analysis, J. Geophys. Res., 108(D9), 4090, doi:10.1029/2003JD001607, 2003.

Anderson, T. L. and Ogren, J. A.: Determining aerosol radiative properties using the TSI 3563 integrating nephelometer, Aerosol Sci. Technol., 29, 57-69, doi:10.1080/02786829808965551, 1998.

Anderson, T. L., Covert, D. S., Marshall, S. F., Laucks, M. L., Charlson, R. J., Waggoner, A. P., Ogren, J. A., Caldow, R., Holm, R. L., Quant, F. R., Sem, G. J., Wiedensohler, A., Ahlquist, N. A., and Bates, T. S.: Performance characteristics of a high-sensitivity, three-wavelength, total scatter/backscatter nephelometer, J. Atmos. Ocean. Tech., 13, 967-986, 1996.

Bahreini, R., Jimenez, J. L., Wang, J., Flagan, R. C., Seinfeld, J. H., Jayne, J. T., and Worsnop, D. R.: Aircraft-based aerosol size and composition measurements during ACE-Asia using an Aerodyne aerosol mass spectrometer, J. Geophys. Res., 108(D23), 8645, doi:10.1029/2002JD003226, 2003.

Baumgardner, D., Kok, G., and Raga, G.: Warming of the Arctic lower stratosphere by light absorbing particles, Geophys. Res. Lett., 31, L06117, doi:10.1029/2003GL018883, 2004.

Bond, T. C. and Bergstrom, R. W.: Light Absorption by Carbonaceous Particles: An Investigative Review, Aerosol Sci. Technol., 40(1), 27-67, doi:10.1080/02786820500421521, 2006.

Bond, T. C., Anderson, T. L., and Campbell, D.: Calibration and intercomparison of filter-based measurements of visible light absorption by aerosols, Aerosol Sci. Technol., 30, 582-600, doi: 10.1080/027868299304435, 1999.
Brink, H. M. T., Veefkind, J. P., Waijers-Ijpelaan, A., and van Der Hage, J. C.: Aerosol light-scattering in The Netherlands, Atmospheric Environment, 30(24), 4251-4261, doi:10.1016/ 1352-2310(96)00091-X, 1996.

Brooks, S. D., DeMott, P. J., and Kreidenweis, S. M.: Water uptake by particles containing humic materials and mixtures of humic materials with ammonium sulfate, Atmos. Environ., 38, 18591868, doi:10.1016/j.atmosenv.2004.01.009, 2004.

Canagaratna, M. R., Jayne, J. T., Jimenez, J. L., Allan, J. D., Alfarra, M. R., Zhang, Q., Onasch, T. B., Drewnick, F., Coe, H., Middlebrook, A., Delia, A. E., Williams, L. R., Trimborn, A. M., Northway, M. J., Decarlo, P. F., Kolb, C. E., Davidovits, P., and Worsnop, D. R.: Chemical and microphysical characterization of ambient aerosols with the aerodyne aerosol mass spectrometer, Mass Spectrom. Rev., 26, 185-222, doi:10.1002/mas.20115, 2007.

Cappa, C. D., Lack, D. A., Burkhardt, J., and Ravishankara, A. R.: Bias in Filter-Based Aerosol Light Absorption Measurements Due to Organic Aerosol Loading: Evidence from Laboratory Measurements, Aerosol Sci. Technol., 42, 1022-1032, 2008.

Carrico, C. M., Kus, P., Rood, M. J., Quinn, P. K., and Bates, T. S.: Mixtures of pollution, dust, sea salt, and volcanic aerosol during ACE-Asia: Radiative properties as a function of relative humidity, J. Geophys. Res., 108(D23), 8650, doi:10.1029/ 2003JD003405, 2003.

Charlson, R. J., Schwartz, S. E., Hales, J. M., Cess, R. D., Coakley, J. A., Hansen, J. E., and Hofmann, D. J.: Climate Forcing by Anthropogenic Aerosols, Science, 255, 423-430, doi:10.1126/ science.255.5043.423, 1992.

Crosier, J., Allan, J. D., Coe, H., Bower, K. N., Formenti, P., and Williams, P. I.: Chemical composition of summertime aerosol in the Po Valley (Italy), northern Adriatic and Black Sea, Q. J. Roy. Meteorol. Soc., 133(S1), 61-75, doi:10.1002/qj.88, 2007.

DeCarlo, P. F., Slowik, J. G., Worsnop, D. R., Davidovits, P., and Jimenez, J. L.: Particle morphology and density characterization by combined mobility and aerodynamic diameter measurements. Part 1: Theory, Aerosol Sci. Technol., 38, 1185-1205, doi:10. 1080/027868290903907, 2004.

DeCarlo, P. F., Kimmel, J. R., Trimborn, A., Northway, M. J., Jayne, J. T., Aiken, A. C., Gonin, M., Fuhrer, K., Horvath, T., Docherty, K. S., Worsnop, D. R., and Jimenez, J. L.: Field-deployable, high-resolution, time-of-flight aerosol mass spectrometer, Anal. Chem., 78, 8281-8289, doi:10.1021/ac061249n, 2006.

Diederen, H. S. M. A., Guicherit, R., and HolLonder, J. C. T.: Visibility reduction by air pollution in The Netherlands, Atmos. Environ., 19, 377-383, doi:10.1016/0004-6981(85)90105-2, 1985.

Dinar, E., Riziq, A. A., Spindler, C., Erlick, C., Kiss, G., and Rudich, Y.: The complex refractive index of atmospheric and model humic-like substances (HULIS) retrieved by a cavity ring down aerosol spectrometer (CRD-AS), Faraday Discuss., 137, 279-295, 2008.

Docherty, K. S., Stone, E. A., Ulbrich, I. M., Decarlo, P. F., Snyder, D. C., Schauer, J. J., Peltier, R. E., Weber, R. J., Murphy, S. N., Seinfeld, J. H., Grover, B. D., Eatough, D. J., and Jimenez, J. L.: Apportionment of Primary and Secondary Organic Aerosols in Southern California during the 2005 Study of Organic Aerosols in Riverside (SOAR-1), Environ. Sci. Technol., 42, 7655-7662, 2008.

Donahue, N. M., Robinson, A. L., Stanier, C. O., and Pandis, 
S. N.: Coupled partitioning, dilution, and chemical aging of semivolatile organics, Environ. Sci. Technol., 40, 2635-2643, doi:10.1021/es052297c, 2006.

Drewnick, F., Hings, S. S., Decarlo, P. F., Jayne, J. T., Gonin, M., Fuhrer, K., Weimer, S., Jimenez, J. L., Demerjian, K. L., Borrmann, S., and Worsnop, D. R.: A new time-of-flight aerosol mass spectrometer (TOF-AMS) - Instrument description and first field deployment, Aerosol Sci. Technol., 39, 637-658, doi: 10.1080/02786820500182040, 2005.

Edwards, J. M. and Slingo, A.: Studies with a flexible new radiation code. 1: Choosing a configuration for a large-scale model, Q. J. Roy. Meteorol. Soc., 122, 689-719, 1996.

Esselborn, M., Wirth, M., Fix, A., Tesche, M., and Ehret, G.: Airborne high spectral resolution lidar for measuring aerosol extinction and backscatter coefficients, Appl. Optics, 47, 346-358, 2008.

Forster, P., Ramaswamy, V., Artaxo, P., Berntsen, T. K., Betts, R., W. Fahey, D. W., Haywood, J., Lean, J., Lowe, D. C., Myhre, G., Nganga, J., Prinn, R., Raga, G., Schulz, M., and Van Dorland, R.: Changes in Atmospheric Constituents and in Radiative Forcing, Climate Change 2007: The Physical Science Basis. Contribution of Working Group I to the Fourth Assessment Report of the Intergovernmental Panel on Climate Change, Cambridge University Press, Cambridge, United Kingdom and New York, NY, USA, 2007.

Gao, R. S., Schwarz, J. P., Kelly, K. K., Fahey, D. W., Watts, L. A., Thompson, T. L., Spackman, J. R., Slowik, J. G., Cross, E. S., Han, J. H., Davidovits, P., Onasch, T. B., and Worsnop, D. R.: A novel method for estimating light-scattering properties of soot aerosols using a modified single-particle soot photometer, Aerosol Sci. Technol., 41(2), 125-135, doi:10.1080/ 02786820601118398, 2007.

Gysel, M., Crosier, J., Topping, D. O., Whitehead, J. D., Bower, K. N., Cubison, M. J., Williams, P. I., Flynn, M. J., McFiggans, G. B., and Coe, H.: Closure study between chemical composition and hygroscopic growth of aerosol particles during TORCH2, Atmos. Chem. Phys., 7, 6131-6144, doi:10.5194/acp-7-61312007, 2007.

Haywood, J., Bush, M., Abel, S., Claxton, B., Coe, H., Crosier, J., Harrison, M., Macpherson, B., Naylor, M., and Osborne, S.: Prediction of visibility and aerosol within the operational Met Office Unified Model. II: Validation of model performance using observational data, Q. J. Roy. Meteorol. Soc., 134, 1817-1832, doi:10.1002/qj.275, 2008.

Haywood, J. M. and Shine, K. P.: The Effect of Anthropogenic Sulfate and Soot Aerosol on the Clear-Sky Planetary Radiation Budget, Geophys. Res. Lett., 22, 603-606, 1995.

Holben, B. N., Eck, T. F., Slutsker, I., Tanre, D., Buis, J. P., Setzer, A., Vermote, E., Reagan, J. A., Kaufman, Y. J., Nakajima, T., Lavenu, F., Jankowiak, I., and Smirnov, A.: AERONET - A federated instrument network and data archive for aerosol characterization, Remote Sens. Environ., 66, 1-16, 1998.

Huffman, J. A., Docherty, K. S., Aiken, A. C., Cubison, M. J., Ulbrich, I. M., DeCarlo, P. F., Sueper, D., Jayne, J. T., Worsnop, D. R., Ziemann, P. J., and Jimenez, J. L.: Chemically-resolved aerosol volatility measurements from two megacity field studies, Atmos. Chem. Phys., 9, 7161-7182, doi:10.5194/acp-9-71612009, 2009.

Jimenez, J. L., Canagaratna, M. R., Donahue, N. M., Prevot, A.
S. H., Zhang, Q., Kroll, J. H., Decarlo, P. F., Allan, J. D., Coe, H., Ng, N. L., Aiken, A. C., Docherty, K. S., Ulbrich, I. M., Grieshop, A. P., Robinson, A. L., Duplissy, J., Smith, J. D., Wilson, K. R., Lanz, V. A., Hueglin, C., Sun, Y. L., Tian, J., Laaksonen, A., Raatikainen, T., Rautiainen, J., Vaattovaara, P., Ehn, M., Kulmala, M., Tomlinson, J. M., Collins, D. R., Cubison, M. J., E., Dunlea, E. J., Huffman, J. A., Onasch, T. B., Alfarra, M. R., Williams, P. I., Bower, K. N., Kondo, Y., Schneider, J., Drewnick, F., Borrmann, S., Weimer, S., Demerjian, K. L., Salcedo, D., Cottrell, L., Griffin, R., Takami, A., Miyoshi, T., Hatakeyama, S., Shimono, A., Sun, J. Y., Zhang, Y. M., Dzepina, K., Kimmel, J. R., Sueper, D., Jayne, J. T., Herndon, S. C., Trimborn, A. M., Williams, L. R., Wood, E. C., Middlebrook, A. M., Kolb, C. E., Baltensperger, U., and Worsnop, D. R.: Evolution of Organic Aerosols in the Atmosphere, Science, 326, 1525-1529, doi:10.1126/science.1180353, 2009.

Kinne, S., Schulz, M., Textor, C., Guibert, S., Balkanski, Y., Bauer, S. E., Berntsen, T., Berglen, T. F., Boucher, O., Chin, M., Collins, W., Dentener, F., Diehl, T., Easter, R., Feichter, J., Fillmore, D., Ghan, S., Ginoux, P., Gong, S., Grini, A., Hendricks, J., Herzog, M., Horowitz, L., Isaksen, I., Iversen, T., Kirkevåg, A., Kloster, S., Koch, D., Kristjansson, J. E., Krol, M., Lauer, A., Lamarque, J. F., Lesins, G., Liu, X., Lohmann, U., Montanaro, V., Myhre, G., Penner, J., Pitari, G., Reddy, S., Seland, O., Stier, P., Takemura, T., and Tie, X.: An AeroCom initial assessment - optical properties in aerosol component modules of global models, Atmos. Chem. Phys., 6, 1815-1834, doi:10.5194/acp-6-1815-2006, 2006.

Kirchstetter, T. W., Novakov, T., and Hobbs, P. V.: Evidence that the spectral dependence of light absorption by aerosols is affected by organic carbon, J. Geophys. Res., 109, D21208, doi:10.1029/ 2004JD004999, 2004.

Kulmala, M., Asmi, A., Lappalainen, H. K., Carslaw, K. S., Pöschl, U., Baltensperger, U., Hov, Ø., Brenquier, J.-L., Pandis, S. N., Facchini, M. C., Hansson, H.-C., Wiedensohler, A., and O'Dowd, C. D.: Introduction: European Integrated Project on Aerosol Cloud Climate and Air Quality interactions (EUCAARI) - integrating aerosol research from nano to global scales, Atmos. Chem. Phys., 9, 2825-2841, doi:10.5194/acp-9-2825-2009, 2009.

Lack, D. A., Cappa, C. D., Covert, D. S., Baynard, T., Massoli, P., Sierau, B., Bates, T. S., Quinn, P. K., Lovejoy, E. R., and Ravishankara, A. R.: Bias in Filter-Based Aerosol Light Absorption Measurements Due to Organic Aerosol Loading: Evidence from Ambient Measurements, Aerosol Sci. Technol., 42, 1033-1041, 2008.

Liu, P., Ziemann, P. J., Kittelson, D. B., and McMurry, P. H.: Generating Particle Beams of Controlled Dimensions and Divergence .1. Theory of Particle Motion in Aerodynamic Lenses and Nozzle Expansions, Aerosol Sci. Technol., 22, 293-313, doi: 10.1080/02786829408959748, 1995a.

Liu, P., Ziemann, P. J., Kittelson, D. B., and McMurry, P. H.: Generating Particle Beams of Controlled Dimensions and Divergence .2. Experimental Evaluation of Particle Motion in Aerodynamic Lenses and Nozzle Expansions, Aerosol Sci. Technol., 22, 314324, doi:10.1080/02786829408959749, 1995b.

Liu, P. S. K., Leaitch, W. R., Strapp, J. W., and Wasey, M. A.: Response of Particle Measuring Systems Airborne ASASP and PCASP to Nacl and Latex-Particles, Aerosol Sci. Technol., 16, 
83-95, doi:10.1080/02786829208959539, 1992.

Massoli, P., Murphy, D. M., Lack, D. A., Baynard, T., Brock, C. A., and Lovejoy, E. R.: Uncertainty in Light Scattering Measurements by TSI Nephelometer: Results from Laboratory Studies and Implications for Ambient Measurements, Aerosol Sci. Technol., 43, 1064-1074, doi:10.1080/02786820903156542, 2009.

McFiggans, G. B., Alfarra, M. R., Allan, J. D., Bower, K. N., Coe, H., Cubison, M. J., Topping, D., Williams, P., Decesari, S., Facchini, C., and Fuzzi, S.: Simplification of the representation of the organic component of atmospheric particulates, Faraday Discuss., 130, 341-362, doi:10.1039/b419435g, 2005.

Mensah, A. A.: Water and Organic Nitrate Detection in an AMS: Laboratory Characterization and Application to Ambient Measurements, Inaugural-dissertation, Universitaet zu Koeln, Cologne, Germany, 2010.

Monks, P. S., Granier, C., Fuzzi, S., Stohl, A., Williams, M. L., Akimoto, H., Amann, M., Baklanov, A., Baltensperger, U., Bey, I., Blake, N., Blake, R. S., Carslaw, K. S., Cooper, O. R., Dentener, F. J., Fowler, D., Fragkou, E., Frost, G. J., Generoso, S., Ginoux, P., Grewe, V., Guenther, A., Hansson, H. C., Henne, S., Hjorth, J., Hofzumahaus, A., Huntrieser, H., Isaksen, I. S. A., Jenkin, M. E., Kaiser, J., Kanakidou, M., Klimont, Z., Kulmala, M., Laj, P., Lawrence, M. G., Lee, J. D., Liousse, C., Maione, M., McFiggans, G. B., Metzger, A., Mieville, A., Moussiopoulos, N., Orlando, J. J., O’Dowd, C. D., Palmer, P. I., Parrish, D. D., Petzold, A., Platt, U., Pöschl, U., Prévôt, A. S. H., Reeves, C. E., Reimann, S., Rudich, Y., Sellegri, K., Steinbrecher, R., Simpson, D., ten Brink, H., Theloke, J., van Der Werf, G. R., Vautard, R., Vestreng, V., Vlachokostas, C., and von Glasow, R.: Atmospheric composition change - global and regional air quality, Atmos. Environ., 43, 5268-5350, doi: 10.1016/j.atmosenv.2009.08.021, 2009.

Morgan, W. T., Allan, J. D., Bower, K. N., Capes, G., Crosier, J., Williams, P. I., and Coe, H.: Vertical distribution of sub-micron aerosol chemical composition from North-Western Europe and the North-East Atlantic, Atmos. Chem. Phys., 9, 5389-5401, doi:10.5194/acp-9-5389-2009, 2009.

Morgan, W. T., Allan, J. D., Bower, K. N., Highwood, E. J., Liu, D., McMeeking, G. R., Northway, M. J., Williams, P. I., Krejci, R., and Coe, H.: Airborne measurements of the spatial distribution of aerosol chemical composition across Europe and evolution of the organic fraction, Atmos. Chem. Phys., 10, 4065-4083, doi:10.5194/acp-10-4065-2010, 2010.

Morino, Y., Kondo, Y., Takegawa, N., Miyazaki, Y., Kita, K., Komazaki, Y., Fukuda, M., Miyakawa, T., Moteki, N., and Worsnop, D. R.: Partitioning of $\mathrm{HNO}_{3}$ and particulate nitrate over Tokyo: Effect of vertical mixing, J. Geophys. Res., 111, D15215, doi:10.1029/2005JD006887, 2006.

Myhre, G., Grini, A., and Metzger, S.: Modelling of nitrate and ammonium-containing aerosols in presence of sea salt, Atmos. Chem. Phys., 6, 4809-4821, doi:10.5194/acp-6-4809-2006, 2006.

Neuman, J. A., Nowak, J. B., Brock, C. A., Trainer, M., Fehsenfeld, F. C., Holloway, J. S., Hubler, G., Hudson, P. K., Murphy, D. M., Nicks, D. K., Orsini, D., Parrish, D. D., Ryerson, T. B., Sueper, D. T., Sullivan, A., and Weber, R.: Variability in ammonium nitrate formation and nitric acid depletion with altitude and location over California, Journal of Geophysical Research, 108(D17), 4557, doi:10.1029/2003JD003616, 2003.
Ng, N. L., Canagaratna, M. R., Zhang, Q., Jimenez, J. L., Tian, J., Ulbrich, I. M., Kroll, J. H., Docherty, K. S., Chhabra, P. S., Bahreini, R., Murphy, S. M., Seinfeld, J. H., Hildebrandt, L., Donahue, N. M., DeCarlo, P. F., Lanz, V. A., Prévôt, A. S. H., Dinar, E., Rudich, Y., and Worsnop, D. R.: Organic aerosol components observed in Northern Hemispheric datasets from Aerosol Mass Spectrometry, Atmos. Chem. Phys., 10, 46254641, doi:10.5194/acp-10-4625-2010, 2010.

Osborne, S. R., Haywood, J. M., and Bellouin, N.: In situ and remote-sensing measurements of the mean microphysical and optical properties of industrial pollution aerosol during ADRIEX, Q. J. Roy. Meteorol. Soc., 133(S1), 17-32, doi: 10.1002/qj.92, 2007.

Oshima, N., Koike, M., Zhang, Y., and Kondo, Y.: Aging of black carbon in outflow from anthropogenic sources using a mixing state resolved model: 2. Aerosol optical properties and cloud condensation nuclei activities, J. Geophys. Res., 114, D18202, doi:10.1029/2008JD011681, 2009.

Paatero, P.: Least squares formulation of robust non-negative factor analysis, Chemometrics and Intelligent Laboratory Systems, 37, 23-35, 1997.

Paatero, P. and Tapper, U.: Positive Matrix Factorization - a Nonnegative Factor Model with Optimal Utilization of ErrorEstimates of Data Values, Environmetrics, 5, 111-126, 1994.

Penner, J. E., Chuang, C. C., and Grant, K.: Climate forcing by carbonaceous and sulfate aerosols, Clim. Dynam., 14, 839-851, 1998.

Petzold, A., Schloesser, H., Sheridan, P. J., Arnott, W. P., Ogren, J. A., and Virkkula, A.: Evaluation of Multiangle Absorption Photometry for Measuring Aerosol Light Absorption, Aerosol Sci. Technol., 39, 40-51, http://www.informaworld.com/10. 1080/027868290901945, 2005.

Pinder, R. W., Adams, P. J., and Pandis, S. N.: Ammonia Emission Controls as a Cost-Effective Strategy for Reducing Atmospheric Particulate Matter in the Eastern United States, Environ. Sci. Technol., 41, 380-386, doi:10.1021/es060379a, 2007.

Putaud, J.-P., Raes, F., Dingenen, R. V., Brüggemann, E., Facchini, M. C., Decesari, S., Fuzzi, S., Gehrig, R., Hüglin, C., Laj, P., Lorbeer, G., Maenhaut, W., Mihalopoulos, N., Müller, K., Querol, X., Rodriguez, S., Schneider, J., Spindler, G., ten Brink, H., Tørseth, K., and Wiedensohler, A.: A European aerosol phenomenology-2: chemical characteristics of particulate matter at kerbside, urban, rural and background sites in Europe, Atmos. Environ., 38, 2579-2595, doi:10.1016/j.atmosenv.2004.01.041, 2004.

Reis, S., Pinder, R. W., Zhang, M., Lijie, G., and Sutton, M. A.: Reactive nitrogen in atmospheric emission inventories, Atmos. Chem. Phys., 9, 7657-7677, doi:10.5194/acp-9-7657-2009, 2009.

Robinson, A. L., Donahue, N. M., Shrivastava, M. K., Weitkamp, E. A., Sage, A. M., Grieshop, A. P., Lane, T. E., Pierce, J. R., and Pandis, S. N.: Rethinking organic aerosols: Semivolatile emissions and photochemical aging, Science, 315, 1259-1262, doi:10.1126/science.1133061, 2007.

Schaap, M., van Loon, M., ten Brink, H. M., Dentener, F. J., and Builtjes, P. J. H.: Secondary inorganic aerosol simulations for Europe with special attention to nitrate, Atmos. Chem. Phys., 4, 857-874, doi:10.5194/acp-4-857-2004, 2004.

Schwarz, J. P., Spackman, J. R., Gao, R. S., Perring, A. E., 
Cross, E., Onasch, T. B., Ahern, A., Wrobel, W., Davidovits, P., Olfert, J., Dubey, M. K., Mazzoleni, C., and Fahey, D. W.: The Detection Efficiency of the Single Particle Soot Photometer, Aerosol Sci. Technol., 44, 612-628, doi:10.1080/02786826. 2010.481298, 2010.

Stephens, M., Turner, N., and Sandberg, J.: Particle Identification by Laser-Induced Incandescence in a Solid-State Laser Cavity, Appl. Optics, 42, 3726, doi:10.1364/AO.42.003726, 2003.

Stokes, R. H. and Robinson, R. A.: Interactions in Aqueous Nonelectrolyte Solutions. I. Solute-Solvent Equilibria, J. Phys. Chem., 70, 2126-2131, doi:10.1021/j100879a010, 1966.

Strapp, J. W., Leaitch, W. R., and Liu, P. S. K.: Hydrated and Dried Aerosol-Size-Distribution Measurements from the Particle Measuring Systems FSSP-300 Probe and the Deiced PCASP-100x Probe, J. Atmos. Ocean. Tech., 9, 548-555, 1992.

Swietlicki, E., Hansson, H. C., Hameri, K., Svenningsson, B., Massling, A., McFiggans, G. B., McMurry, P. H., Petaja, T., Tunved, P., Gysel, M., Topping, D., Weingartner, E., Baltensperger, U., Rissler, J., Wiedensohler, A., and Kulmala, M.: Hygroscopic properties of submicrometer atmospheric aerosol particles measured with H-TDMA instruments in various environments - a review, Tellus B, 60, 432-469, 2008.

Tang, I. N.: Chemical and size effects of hygroscopic aerosols on light scattering coefficients, J. Geophys. Res., 101, 1924519250, doi:10.1029/96JD03003, 1996.

Textor, C., Schulz, M., Guibert, S., Kinne, S., Balkanski, Y., Bauer, S., Berntsen, T., Berglen, T., Boucher, O., Chin, M., Dentener, F., Diehl, T., Easter, R., Feichter, H., Fillmore, D., Ghan, S., Ginoux, P., Gong, S., Grini, A., Hendricks, J., Horowitz, L., Huang, P., Isaksen, I., Iversen, I., Kloster, S., Koch, D., Kirkevåg, A., Kristjansson, J. E., Krol, M., Lauer, A., Lamarque, J. F., Liu, X., Montanaro, V., Myhre, G., Penner, J., Pitari, G., Reddy, S., Seland, Ø., Stier, P., Takemura, T., and Tie, X.: Analysis and quantification of the diversities of aerosol life cycles within AeroCom, Atmos. Chem. Phys., 6, 1777-1813, doi:10.5194/acp-61777-2006, 2006.
Toon, O. B., Pollack, J. B., and Khare, B. N.: Optical-Constants Of Several Atmospheric Aerosol Species - Ammonium-Sulfate, Aluminum-Oxide, And Sodium-Chloride, J. Geophys. Res., 81, 5733-5748, 1976.

Ulbrich, I. M., Canagaratna, M. R., Zhang, Q., Worsnop, D. R., and Jimenez, J. L.: Interpretation of organic components from Positive Matrix Factorization of aerosol mass spectrometric data, Atmos. Chem. Phys., 9, 2891-2918, doi:10.5194/acp-9-2891-2009, 2009.

Van Ulden, A. P. and Wieringa, J.: Atmospheric boundary layer research at Cabauw, Bound.-Lay. Meteorol., 78, 39-69, 1996.

Wandinger, U., Müller, D., Böckmann, C., Althausen, D., Matthias, V., Bösenberg, J., Weiß, V., Fiebig, M., Wendisch, M., Stohl, A., and Ansmann, A.: Optical and microphysical characterization of biomass-burning and industrial-pollution aerosols from multiwavelength lidar and aircraft measurements, J. Geophys. Res., 107(D21), 8125, doi:10.1029/2000JD000202, 2002.

Weast, R. C.: Handbook of Chemistry and Physics, 66th edition, CRC Press, Florida, 1985.

White, W. H. and Roberts, P. T.: Nature and Origins of VisibilityReducing Aerosols in Los Angeles Air Basin, Atmos. Environ., 11, 803-812, doi:10.1016/0004-6981(77)90042-7, 1977.

Zhang, Q., Jimenez, J. L., Canagaratna, M. R., Allan, J. D., Coe, H., Ulbrich, I., Alfarra, M. R., Takami, A., Middlebrook, A. M., Sun, Y. L., Dzepina, K., Dunlea, E. J., Docherty, K. S., Decarlo, P. F., Salcedo, D., Onasch, T., Jayne, J. T., Miyoshi, T., Shimono, A., Hatakeyama, S., Takegawa, N., Kondo, Y., Schneider, J., Drewnick, F., Borrmann, S., Weimer, S., Demerjian, K. L., Williams, P., Bower, K. N., Bahreini, R., Cottrell, L., Griffin, R. J., Rautiainen, J., Sun, J. Y., Zhang, Y. M., and Worsnop, D. R.: Ubiquity and dominance of oxygenated species in organic aerosols in anthropogenically-influenced Northern Hemisphere midlatitudes, Geophys. Res. Lett., 34, L13801, doi:10. 1029/2007GL029979, 2007. 